Supplement of

\title{
Characterization of nighttime formation of particulate organic nitrates based on high-resolution aerosol mass spectrometry in an urban atmosphere in China
}

Kuangyou Yu et al.

Correspondence to: Xiao-Feng Huang (huangxf@pku.edu.cn)

The copyright of individual parts of the supplement might differ from the CC BY 4.0 License. 


\section{List of supporting information:}

\section{Text S1: Nitrate radicals estimation}

Figure S1.Time series of $\mathrm{PM}_{1}$ species for spring (a), summer (b) and autumn (c).

Figure S2.Mass spectrumprofiles of 3 factors (a), 4 factors (b) and 5 factors (c) based on PMF analysis, and diagnostic plots of the chosen (3 factors) PMF solution (d) for spring: (1) Q/Qexp vs number of factors; (2) the time series of the measured and the reconstructed organic mass; (3) Q/Qexp vs. FPEAK for the solution with optimal number of factors; (4) the distribution of scaled residuals for each m/z; (5) mass fraction of PMF factors vs. FPEAK; (6) correlations of time series and mass spectra among PMF factors.

Figure S3.Mass spectrumprofiles of 3 factors (a), 4 factors (b) and 5 factors (c) based on PMF analysis, and diagnostic plots of the chosen (3 factors) PMF solution (d) for summer: (1) Q/Qexp vs number of factors; (2) the time series of the measured and the reconstructed organic mass; (3) Q/Qexp vs. FPEAK for the solution with optimal number of factors; (4) the distribution of scaled residuals for each m/z; (5) mass fraction of PMF factors vs. FPEAK; (6) correlations of time series and mass spectra among PMF factors.

Figure S4.Mass spectrumprofiles of 3 factors (a), 4 factors (b) and 5 factors (c) based on PMF analysis, and diagnostic plots of the chosen (3 factors) PMF solution (d) for autumn: (1) Q/Qexp vs number of factors; (2) the time series of the measured and the reconstructed organic mass; (3) Q/Qexp vs. FPEAK for the solution with optimal number of factors; (4) the distribution of scaled residuals for each m/z; (5) mass fraction of PMF factors vs. FPEAK; (6) correlations of time series and mass spectra among PMF factors.

Figure S5.Diurnal cycles for NR-PM 1 species and OA factors in spring (a), summer (b) and autumn (c)

Figure S6. Mass spectra of the OA factors resolved from the PMF analysis on high-resolution merged organic and nitrate mass spectra (i.e., $\mathrm{PMF}_{\mathrm{Org}+\mathrm{NO} 3}$ analysis) for (a) spring, (b) summer, (c) autumn and (d) winter.

Figure S7.Scatter plots of $\mathrm{NO}_{3 . \text { org1_ratio }}$ with $\mathrm{HOA}$ and MO-OOA in spring for the whole day (a), at nighttime (b) and during the day (c).

Figure S8.Scatter plots of $\mathrm{NO}_{3 . \text { org1_ratio }}$ with $\mathrm{HOA}$ and $\mathrm{MO}-\mathrm{OOA}$ in summer for the whole day (a), at nighttime (b) and during the day (c).

Figure S9.Scatter plots of $\mathrm{NO}_{3 . \text {.org1_ratio }}$ with $\mathrm{HOA}$ and MO-OOA in autumn for the whole day (a), at nighttime (b) and during the day (c).

Figure S10. Time series of the contributions of $\mathrm{CH}_{2} \mathrm{O}^{+}$in m/z 30 and $\mathrm{CH}_{2} \mathrm{O}_{2}{ }^{+}$in $\mathrm{m} / \mathrm{z} 46$ in the HR data of $\mathrm{PM}_{1}$ for spring (a), summer (b), autumn (c) and winter (d). (High-resolution mass spectra at $\mathrm{m} / \mathrm{z} 46$ only contains $\mathrm{NO}_{2}{ }^{+}$in spring, autumn and winter).

Figure S11. Average size distributions of m/z 30 and m/z 46 in spring (a), summer (b), autumn (c) and winter (d).

Figure S12. Average size distributions of $\mathrm{m} / \mathrm{z} 30 / \mathrm{m} / \mathrm{z} 46$ ratio under under highest $(>15 \%)$ and lowest interferences $(<5 \%)$ $\mathrm{CH}_{2} \mathrm{O}_{\mathrm{X}}{ }^{+}$interferences in spring (a), summer (b), autumn (c). 
Figure S13. Average size distributions of organic and inorganic nitrates calculated using the size distributions of $\mathrm{m} / \mathrm{z} 30 / \mathrm{m} / \mathrm{z}$ 46 ratio and $\mathrm{NO}^{+} / \mathrm{NO}_{2}{ }^{+}$ratio method in spring (a), summer (b), autumn (c).

Figure S14. Diurnal trends of relative humidity $(\mathrm{RH})$, temperature, $\mathrm{NO}_{2}, \mathrm{O}_{3}$ and calculated $\mathrm{NO}_{3}$ radicals in spring (The solid lines indicate the mean concentration and the error bars indicate the standard error).

Figure S15. (a) Correlations between NO3_org_ratio_1 with PP of $\alpha$-pinene, limonene, styrene and camphene during 2:006:00 for the spring campaign; (b) Correlation between LO-OOA with PP of $\alpha$-pinene, limonene, styrene and camphene during 2:00-6:00 for the spring campaign; (c) Correlation between BC with PP of $\alpha$-pinene, limonene, styrene and camphene during 2:00-6:00 for the spring campaign

Figure S16.Corre lation of $\mathrm{NO}_{3 \_ \text {org_ratio_1 }}$ and $\mathrm{NO}_{2}(\mathrm{a})$; $\mathrm{NO}_{3} \_$org_ratio_1 and VOCs (the sum of $\alpha$-pinene, limonene, styrene and camphene) (b); $\mathrm{NO}_{3}$ _org_PMF and $\mathrm{NO}_{2}$ (c) and $\mathrm{NO}_{3}$ _org_PMF and VOCs (the sum of $\alpha$-pinene, limonene, styrene and camphene) (d) during the springtime.

Table S1.The correlation coefficients (R) of $\mathrm{NO}_{3}$, org and $\mathrm{NO}_{3}$, inorg in 3- to 5-factors solutions estimated by PMF method with these estimated by NOx method, respectively.

Table S2. The mass fraction of $\mathrm{NO}+$ and $\mathrm{NO} 2+$ in $\mathrm{OA}$ factors when FPEA K is 0 and the standard deviations (SD) of NO+ and NO2+ in OA factors across different FPEAK values (from -1.0 to 1.0).

Table S3. The average campaign concentrations of VOCs measured with an automated in situ gas-chromatography mass spectrometer (GC-MS), their reaction rate coefficients for reacting with $\mathrm{NO}_{3}$ radicals and the production potential from $\mathrm{NO} 3+\mathrm{VOC}$ in spring.

\section{Text S1: Nitrate radicals estimation}

The approach of nitrates radical estimation is similar to $\mathrm{Xu}$ et al. (2015). Noted that only springtime $\mathrm{NO}_{3}$ radicals are calculated because only VOCs concentrations have been measured in spring. The average concentration of VOCs and the reaction rate coeffic ients of $\mathrm{NO}_{3}+\mathrm{VOCs}$ at $25^{\circ} \mathrm{C}$ at night are listed in Table $\mathrm{S} 3 . \mathrm{NO}_{3}$ radical is the product of $\mathrm{NO}_{2}+\mathrm{O}_{3}$, and its losses react with individual VOCs, $\mathrm{NO}$ and photolysis. Due to the existence of $\mathrm{N}_{2} \mathrm{O}_{5}$ in equilibrium with $\mathrm{NO}_{2}+\mathrm{NO}_{3}$, we should first estimate the sinks of $\mathrm{N}_{2} \mathrm{O}_{5}$ impcting the life of nitrate radicals. There are both heterogenous and homogeneous reactions of $\mathrm{N}_{2} \mathrm{O}_{5}$ with water. The $\mathrm{N}_{2} \mathrm{O}_{5}$ lifetime, with respect to the heterogeneous uptake of aqueous particles, is (Dentener and Crutzen, 1993):

$$
\tau_{N 2 O 5, \text { het }}=\frac{1}{K_{h e t}}=\frac{4}{S A \cdot \gamma \cdot v}
$$

where $K_{\text {het }}$ represents the rate of heterogeneous uptake, SA represents the surface area of the particles calculated from the size-resolved particle number concentrations assuming spherical particles measured by SMPS, and then the SA under dry condition should be converted to ambient (wet) aerosol SA. In this study, the average ambient (wet) aerosol SA is $475 \mu \mathrm{m}^{2}$ $\mathrm{cm}^{-3}$ corrected by using the hygroscopic growth factor in Liu et al. (2010). $\gamma$ is the uptake coefficient and we use the upperlimit values of 0.04 according on uptake coefficient on liquid water measurement (Saunders et al., 2003), v represents the 
molecular speed $\left(2.3 * 10^{4} \mathrm{~cm} \mathrm{~s}^{-1}\right)$, this gives an average $\mathrm{N}_{2} \mathrm{O}_{5}$ lifetime $\tau_{N 205 \text {, het }}$ of $915 \mathrm{~s}$. In addition, the $\mathrm{N}_{2} \mathrm{O}_{5}$ lifetime, with respect to the reaction with $\mathrm{H}_{2} \mathrm{O}$, is (Crowley et al., 2011):

$$
\tau_{N 2 O 5, H 2 O}=\frac{1}{K_{H 2 O}}=\frac{1}{2.5 \times 10^{-22}\left[H_{2} O\right]+1.8 \times 10^{-39}\left[\mathrm{H}_{2} \mathrm{O}\right] 2}
$$

$K_{H 2 O}$ represents the reaction rate of $\mathrm{N}_{2} \mathrm{O}_{5}$ and $\mathrm{H}_{2} \mathrm{O}$, and $\left[\mathrm{H}_{2} \mathrm{O}\right]$ represents the water concentration (unit of molecule $\mathrm{cm}^{-3}$ ); the daily maximu $\left[\mathrm{H}_{2} \mathrm{O}\right]$ is $5.5^{*} 10^{17}$ molecule $\mathrm{cm}^{-3}$ at 6:00 during the sampling period, and the calcu lated value is $1470 \mathrm{~s}$. Then, we estimate the $\mathrm{NO}_{3}$ lifetime by only considering the reaction with VOCs $\left(\tau_{N O 3, V O C S}\right)$ :

$$
\tau_{N O 3, V O C s}=\frac{1}{\sum k_{i\left[V_{i}\right]}}
$$

The average lifetime of $\mathrm{NO}_{3}$ is approximately $14.08 \mathrm{~s}$. Based on the estimation of the $\mathrm{N}_{2} \mathrm{O}_{5}$ and $\mathrm{NO}_{3}$ lifetimes above, we can conclude that the influence of $\mathrm{N}_{2} \mathrm{O}_{5}$ could be ignored when estimating the $\mathrm{NO}_{3}$ concentration and, due to the high reactivity of $\mathrm{NO}_{3}(14.08 \mathrm{~s})$, the steady-state $\mathrm{NO}_{3}$ can be predicted:

$$
\left[\mathrm{NO}_{3} \cdot\right]=\frac{k_{1}\left[\mathrm{O}_{3}\right]\left[\mathrm{NO}_{2}\right]}{J_{\mathrm{NO} 3}+k_{2}[\mathrm{NO}]+\sum k_{i}\left[\mathrm{VOC}_{i}\right]}
$$
where $J_{N O 3}$ is calculated from the solar zenith angles and $\mathrm{NO}_{3}$ photolysis rates (Saunders et al., 2003) and, in this study, the typical value of $J_{N O 3}$ is $0.12 \mathrm{~s}^{-1}$ during the daytime. $k_{1}$ is $3.52 * 10^{-17} \mathrm{~cm}^{3}$ molecule ${ }^{-1} \mathrm{~s}^{-1}$, and $k_{2}$ is $2.7^{*} 10^{-11} \mathrm{~cm}^{3}$ molecule ${ }^{-1} \mathrm{~s}^{-1}$ according to the Master Chemical Mechanism model (http://mcm.leeds.ac.uk/MCM/; under $25^{\circ} \mathrm{C}$ ). 


\section{(a) Spring}
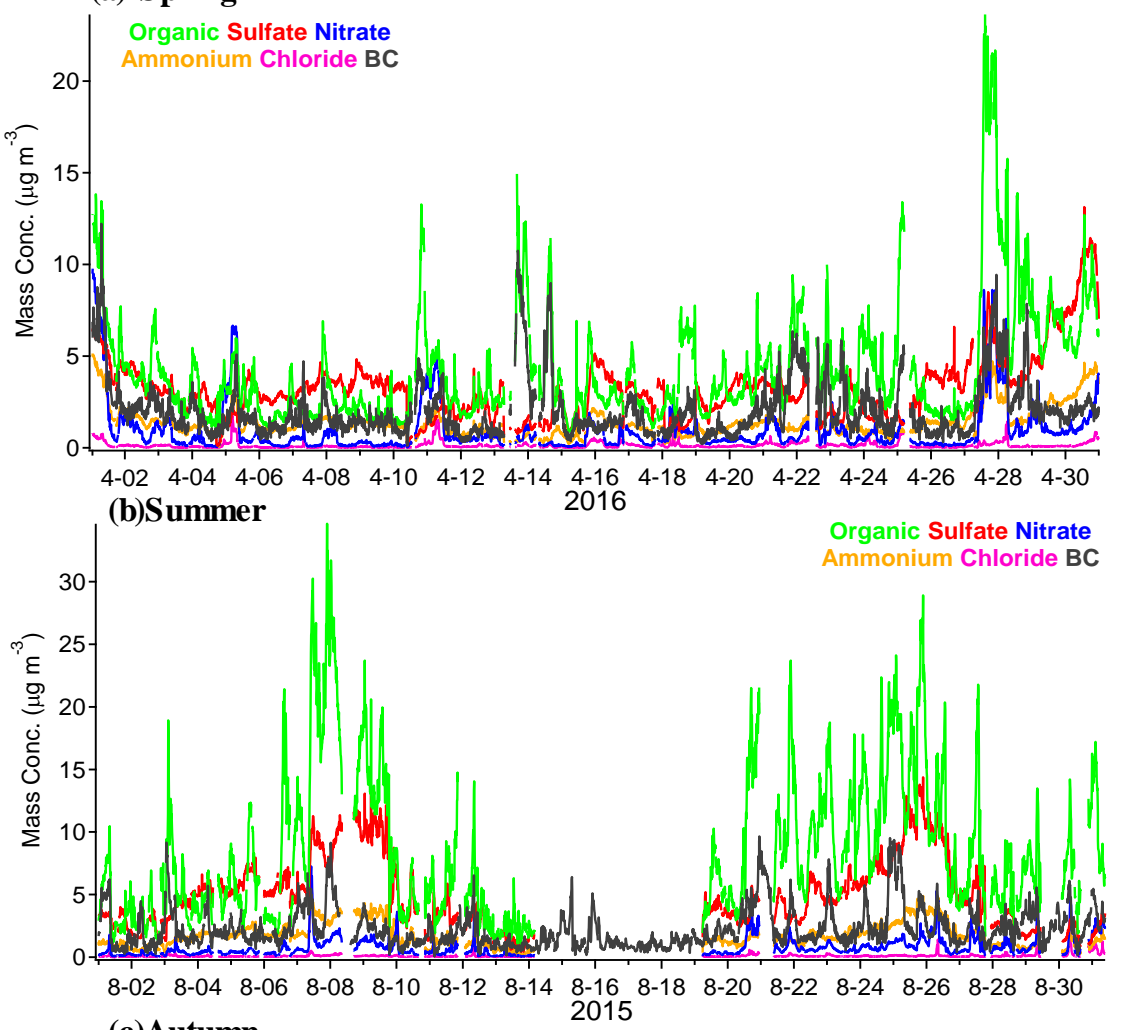

\section{(c)Autumn}

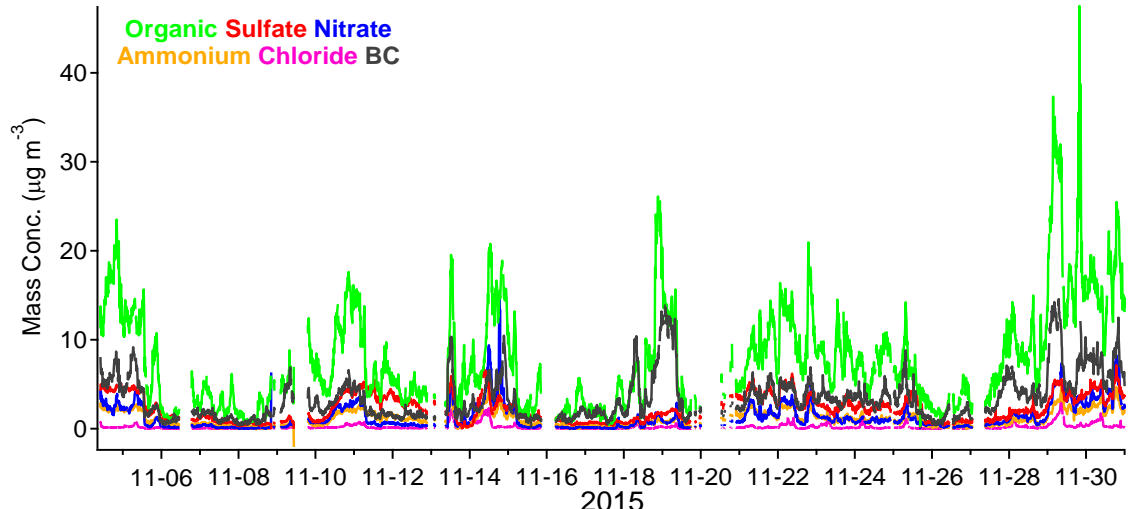

Figure S1.Time series of $\mathrm{PM}_{1}$ species for spring (a), summer (b) and autumn (c). 

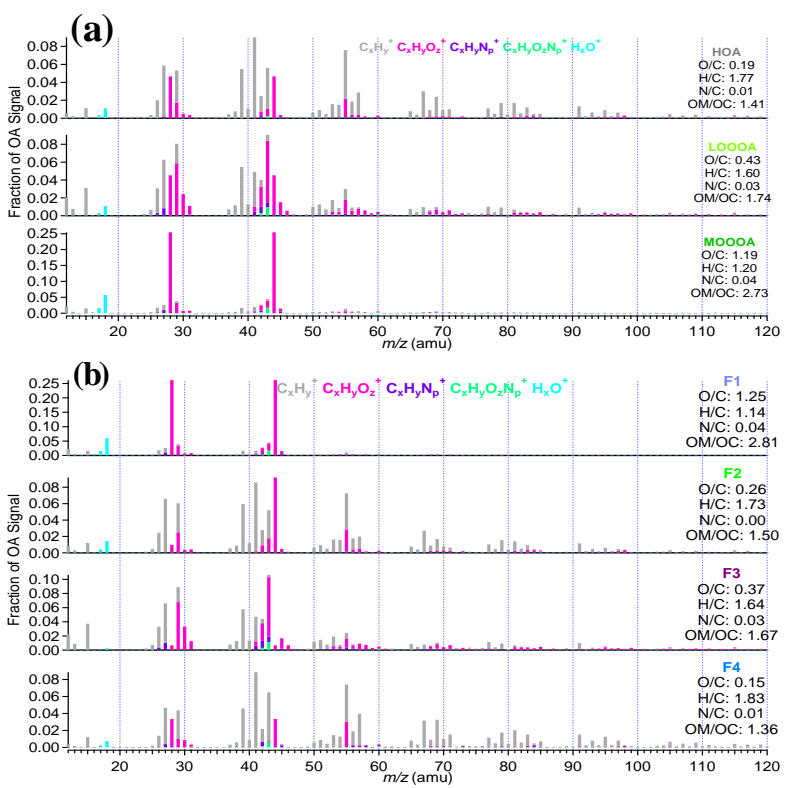

(c)
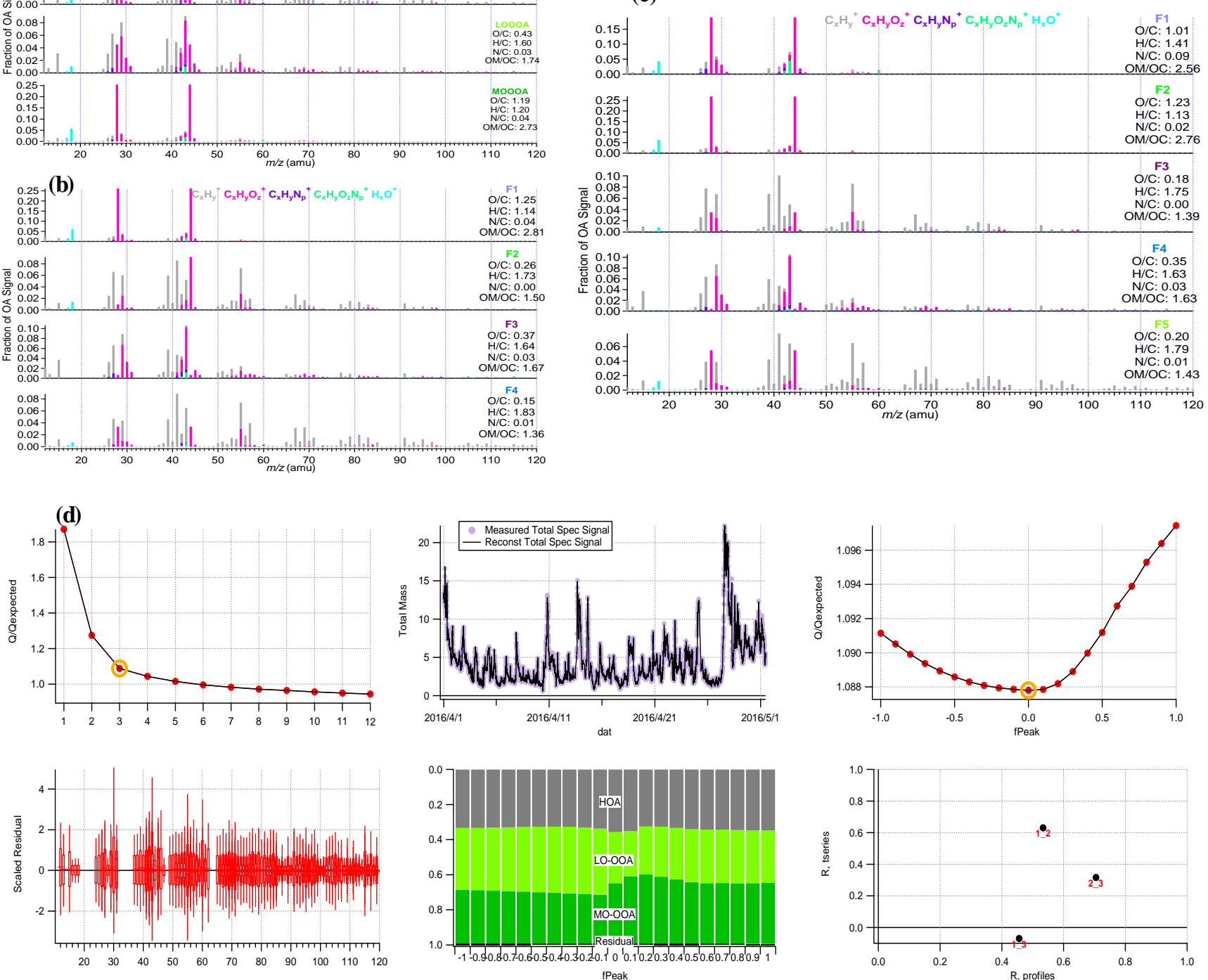

Figure S2.Mass spectrumprofiles of 3 factors (a), 4 factors (b) and 5 factors (c) based on PMF analysis, and diagnostic plots of the chosen (3 factors) PMF solution (d) for spring: (1) Q/Qexp vs number of factors; (2) the time series of the measured and the reconstructed organic mass; (3) Q/Qexp vs. FPEAK for the solution with optimal number of factors; (4) the distribution of scaled residuals for each m/z; (5) mass fraction of PMF factors vs. FPEAK; (6) correlations of time series and mass spectra among PMF factors. 
(a)
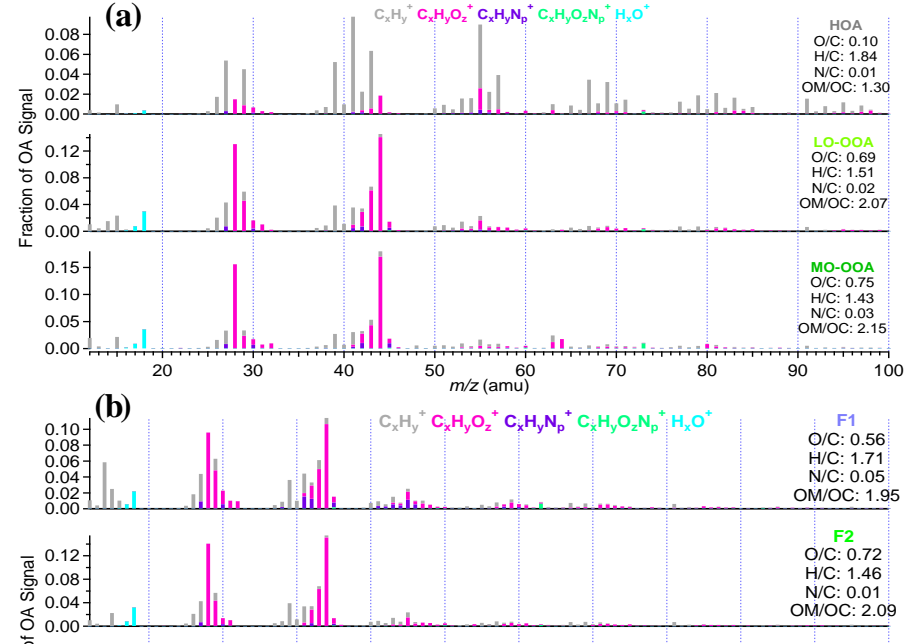

등 0.15
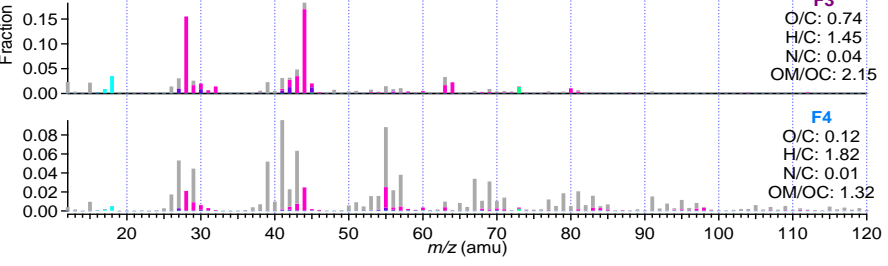

(c)

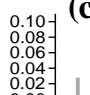

$\mathrm{C}_{x} \mathrm{H}_{y}{ }^{+} \mathrm{C}_{x} \mathrm{H}_{\mathrm{y}} \mathrm{O}_{z}{ }^{+} \mathrm{C}_{x} \mathrm{H}_{\mathrm{y}} \mathrm{N}_{\mathrm{p}}{ }^{+} \mathrm{C}_{\mathrm{x}} \mathrm{H}_{\mathrm{y}} \mathrm{O}_{\mathrm{z}} \mathrm{N}_{\mathrm{p}}{ }^{+} \mathrm{H}_{\mathrm{x}} \mathrm{O}^{+}$

F1 N/C: 0.03 OM/OC: 1.60
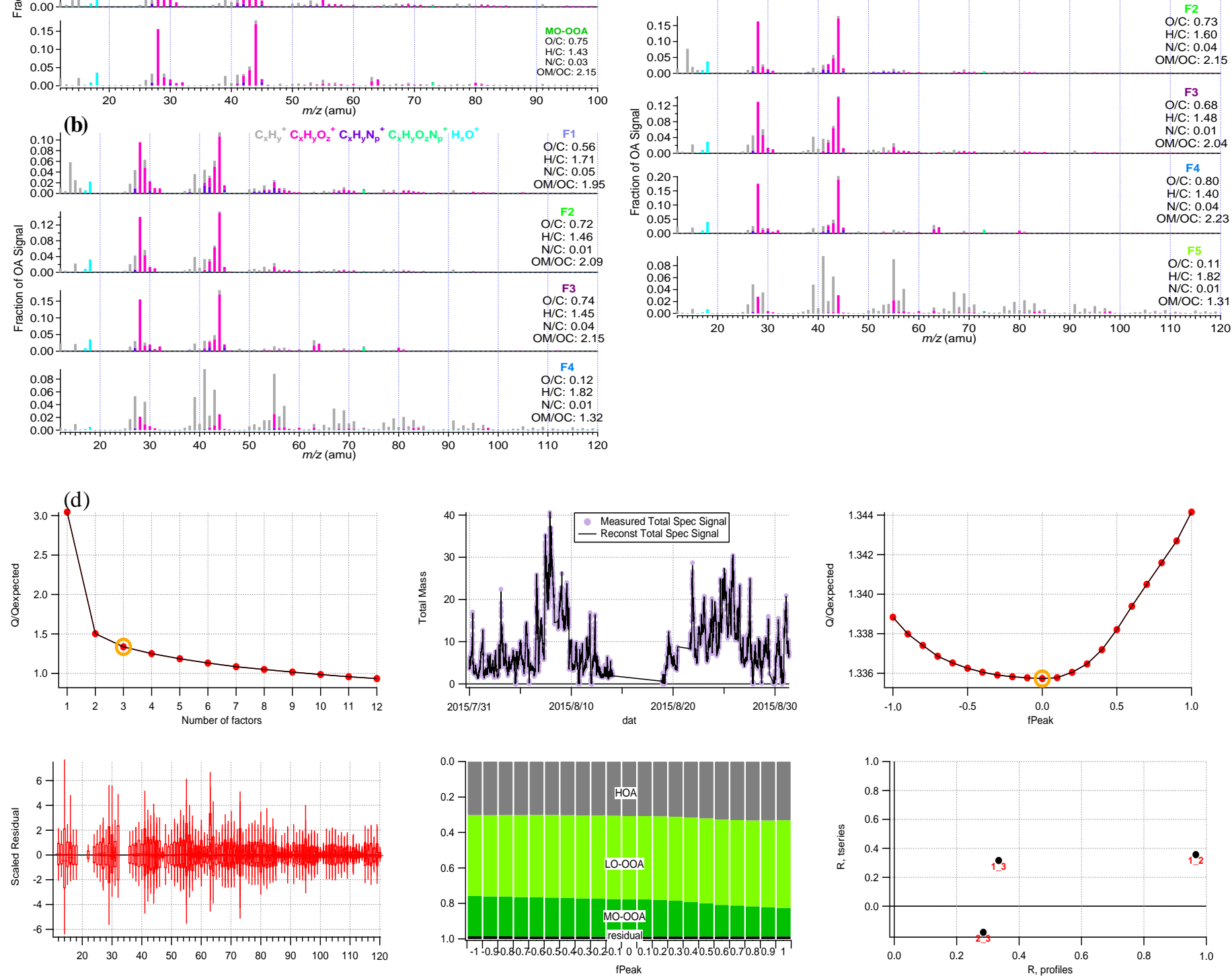

Figure S3.Mass spectrumprofiles of 3 factors (a) , 4 factors (b) and 5 factors (c) based on PMF analysis, and diagnostic plots of the chosen (3 factors) PMF solution (d) for summer: (1) Q/Qexp vs number of factors; (2) the time series of the measured and the reconstructed organic mass; (3) Q/Qexp vs. FPEAK for the solution with optimal number of factors; (4) the distribution of scaled residuals for each $\mathrm{m} / \mathrm{z}$; (5) mass fraction of PMF factors vs. FPEAK; (6) correlations of time serie s and mass spectra among PMF factors. 

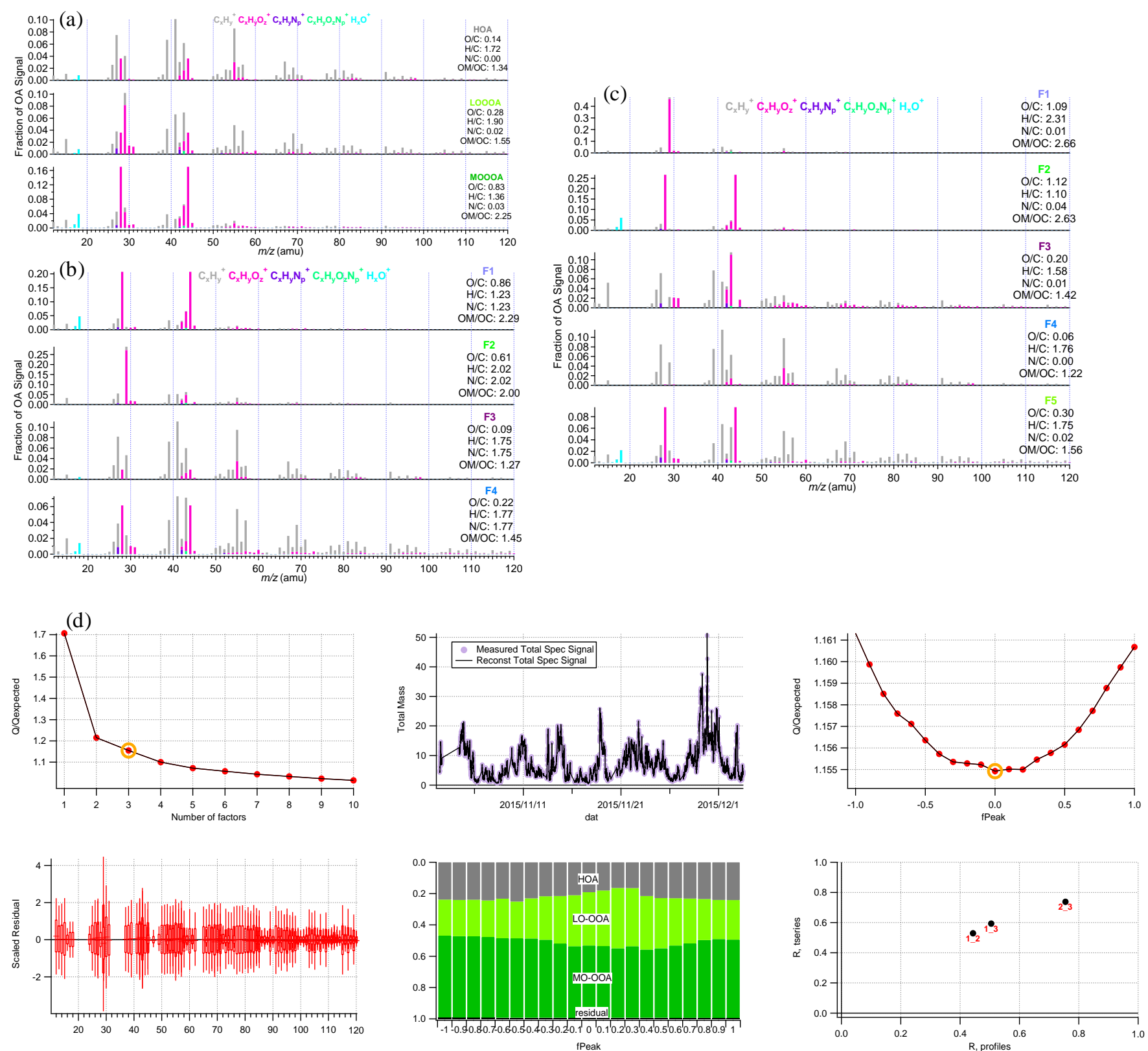

Figure S4.Mass spectrumprofiles of 3 factors (a) , 4 factors (b) and 5 factors (c) based on PMF analysis, and diagnostic plots of the chosen (3 factors) PMF solution (d) for Autumn: (1) Q/Qexp vs number of factors; (2) the time series of the measured and the reconstructed organic mass; (3) Q/Qexp vs. FPEAK for the solution with optimal number of factors; (4) the distribution of scaled residuals for each $\mathrm{m} / \mathrm{z}$; (5) mass fraction of PMF factors vs.FPEAK; (6) correlations of time series and mass spectra among PMF factors. 


\section{(a) Spring}
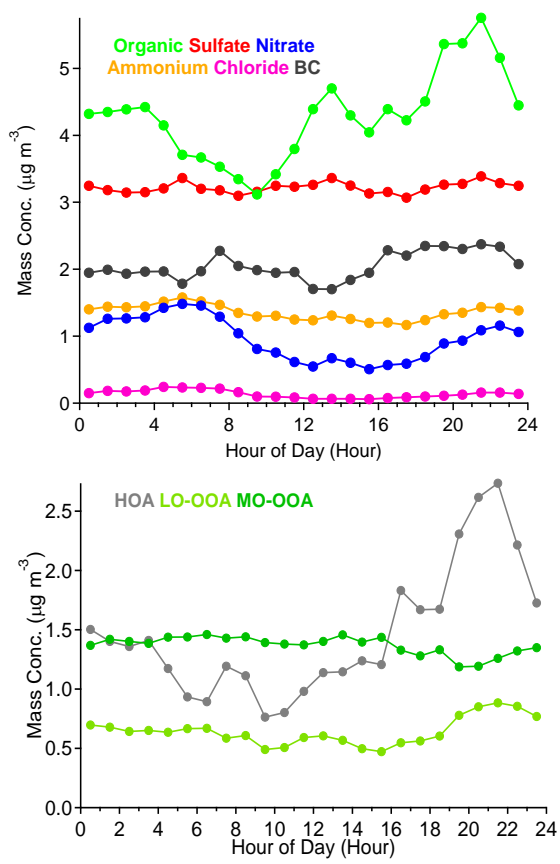

(b) Summer
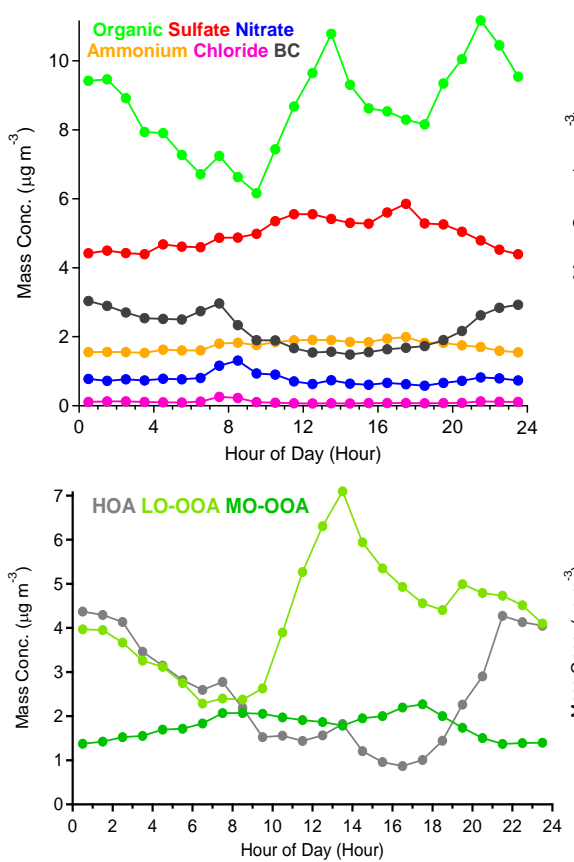

(c) Autumn
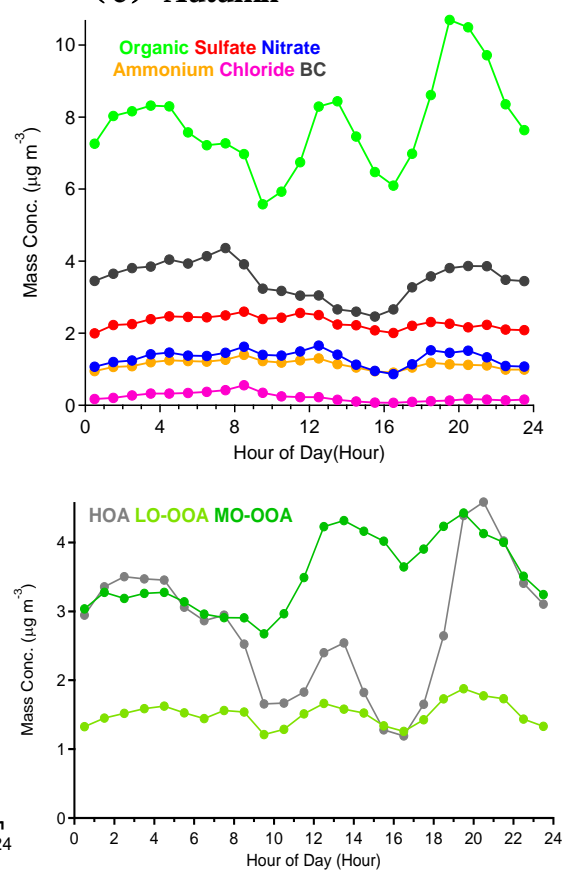

Figure S5.Diurnal cycles for NR-PM 1 species and OA factors in spring (a), summer (b) and autumn (c). 


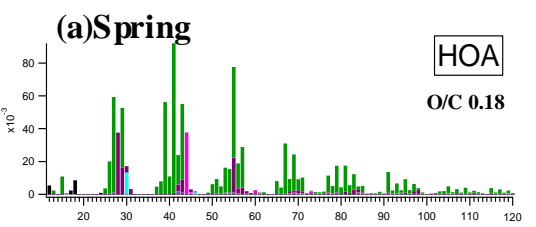

\section{(b)Summer}
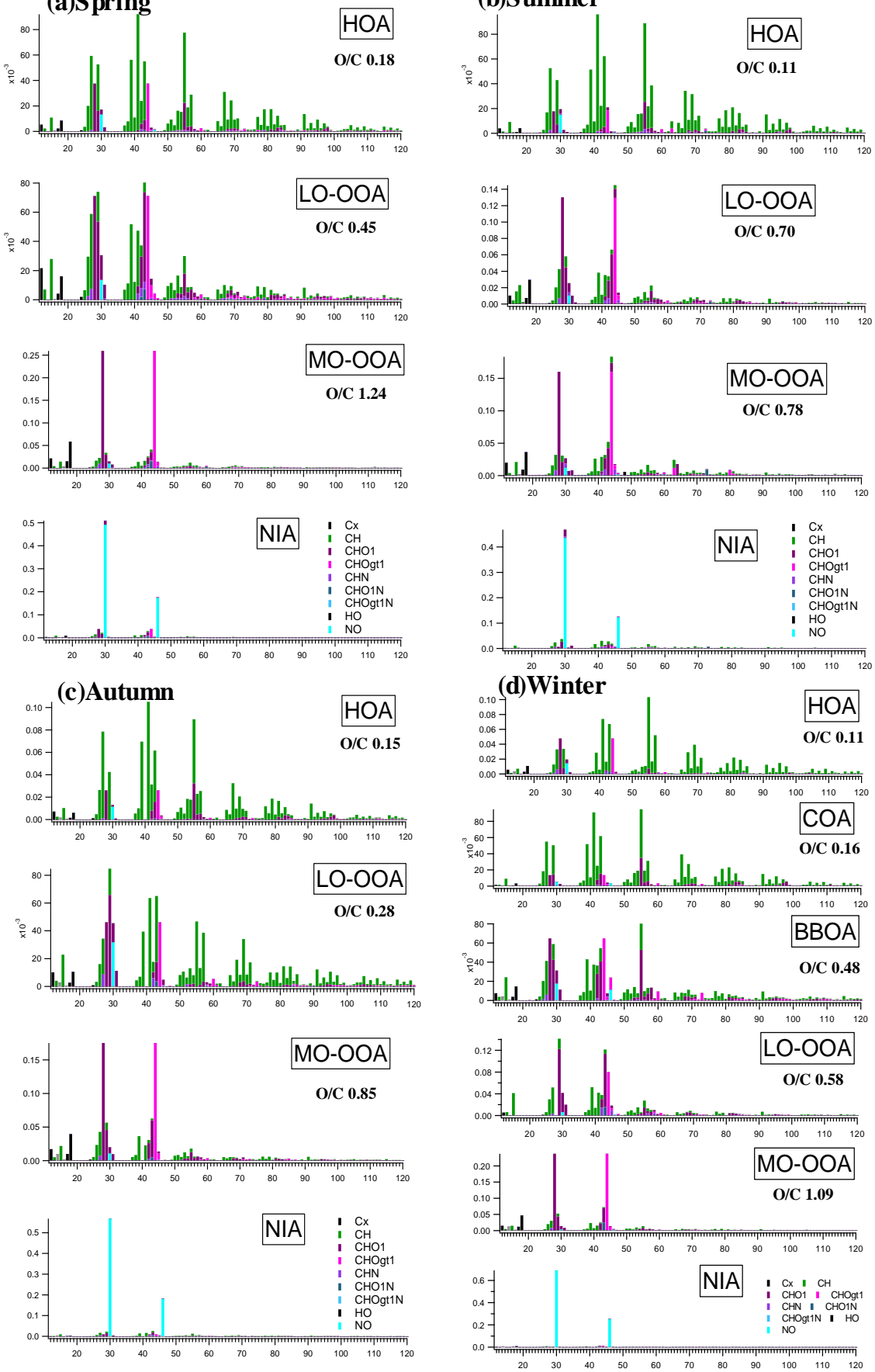
(a) Whole day

(b) Nighttime

(c) Daytime
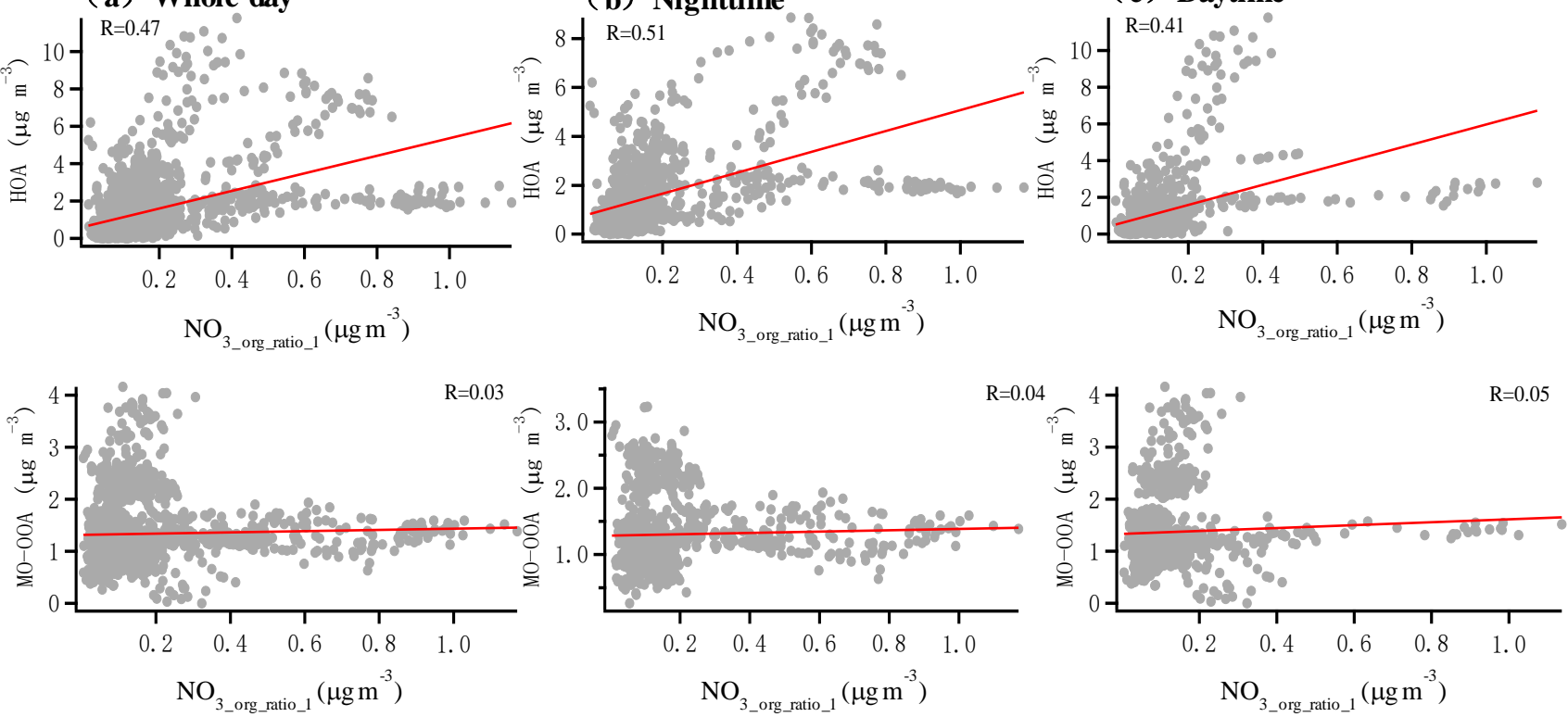

Figure S7.Scatter plots of $\mathrm{NO}_{3 \_ \text {or__ratio_1 }}$ with $\mathrm{HOA}$ and MO-OOA in spring for the whole day (a), at nighttime (b) and during the day (c).
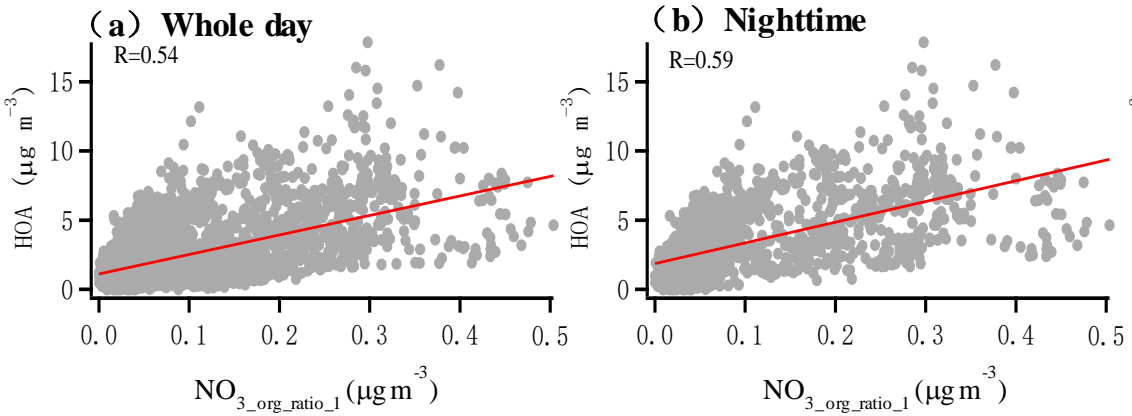

(c) Daytime
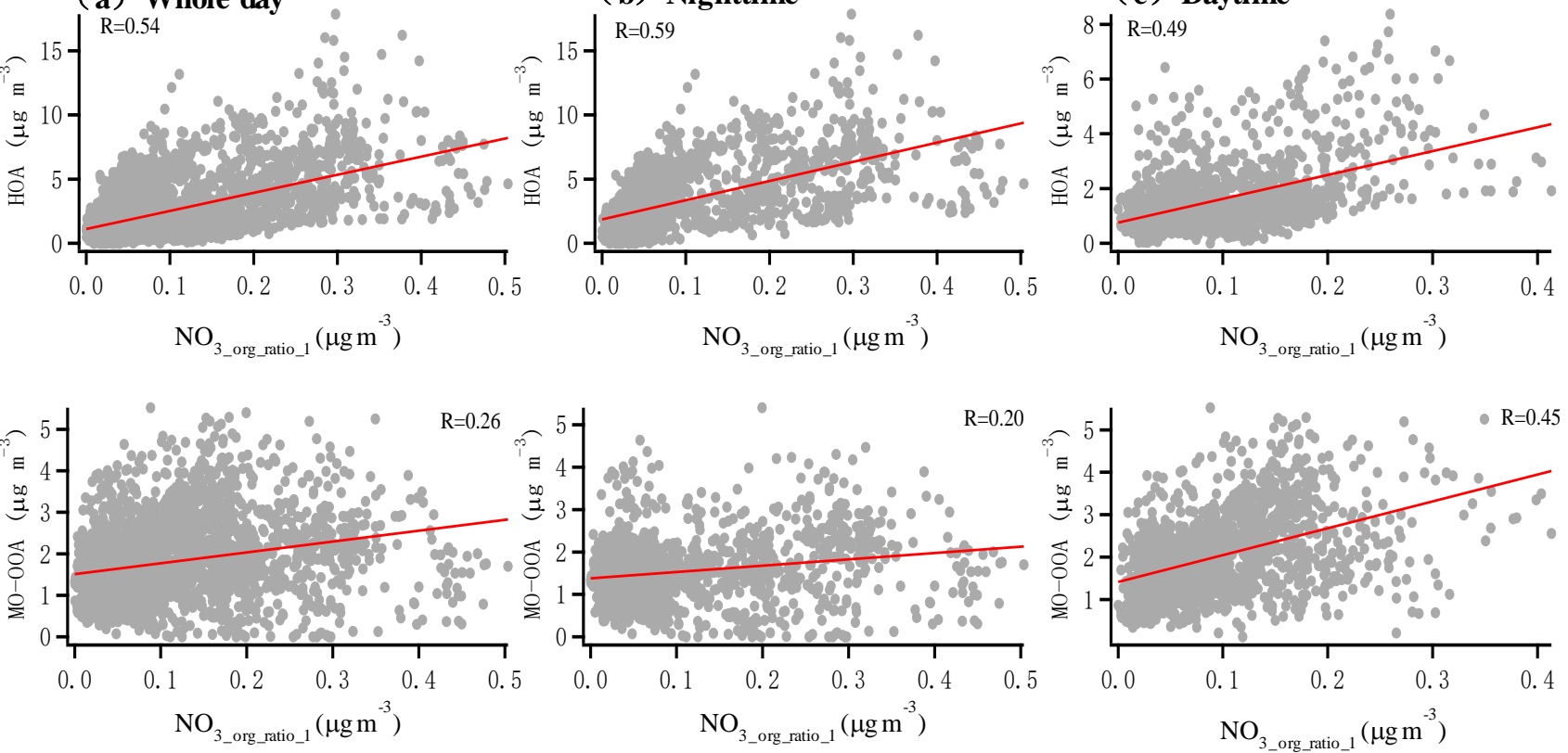

115

116

Figure S8.Scatter plots of $\mathrm{NO}_{3 \text { _or__ratio_1 }}$ with $\mathrm{HOA}$ and $\mathrm{MO}-\mathrm{OOA}$ in summer for the whole day (a), at nighttime (b) and during the day (c). 
(a) Whole day
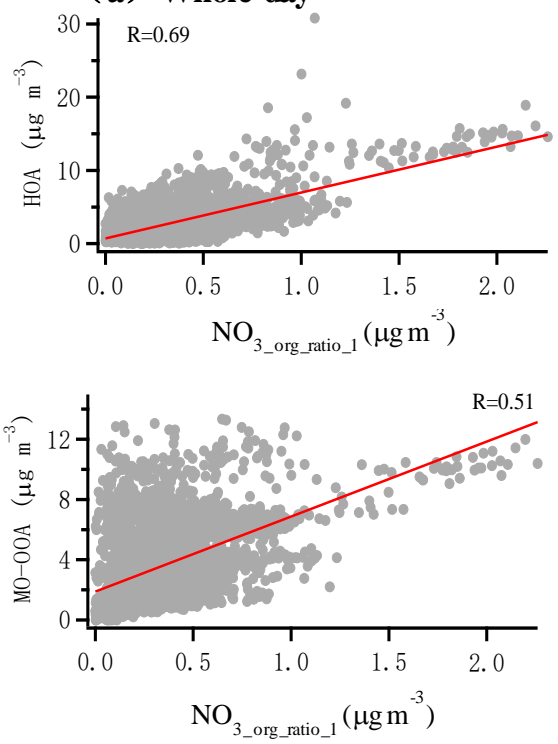

(b) Nighttime
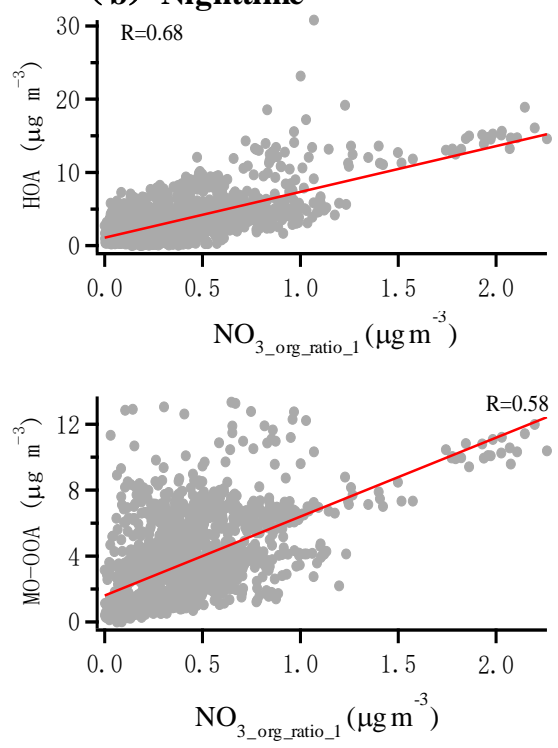

(c) Daytime
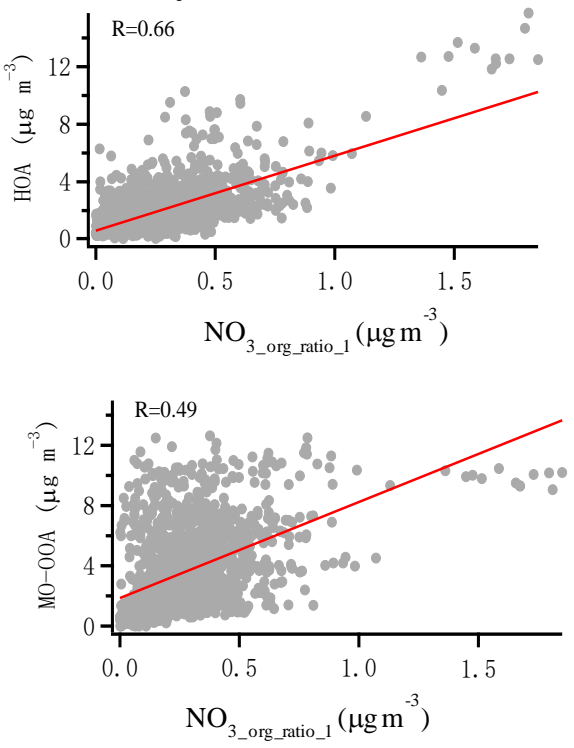

Figure S9.Scatter plots of $\mathrm{NO}_{3 \_ \text {org_ratio_1 }}$ with $\mathrm{HOA}$ and MO-OOA in autumn for the whole day (a), at nighttime (b) and during the day (c). 
(a) Spring
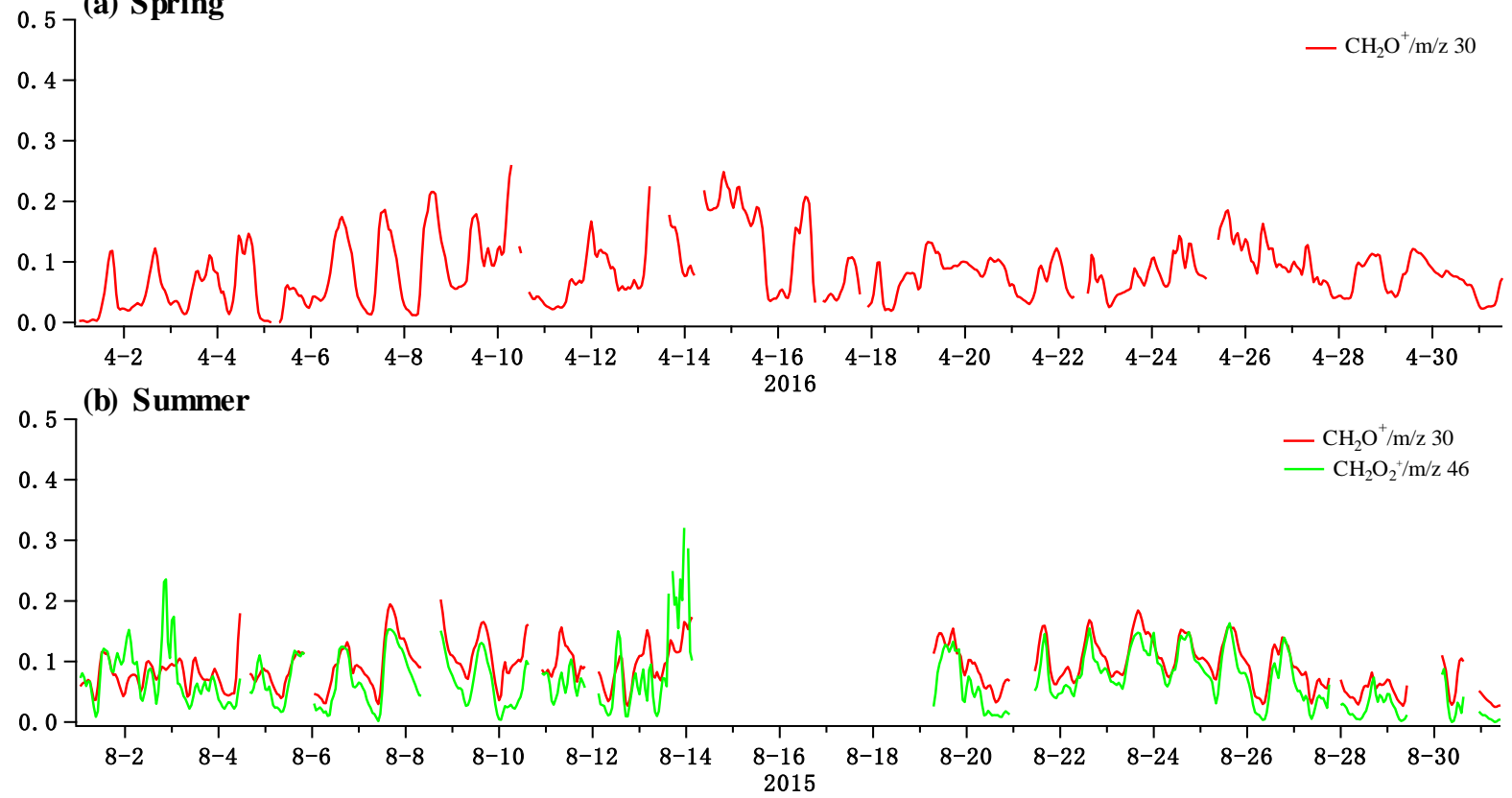

(c) Autumn
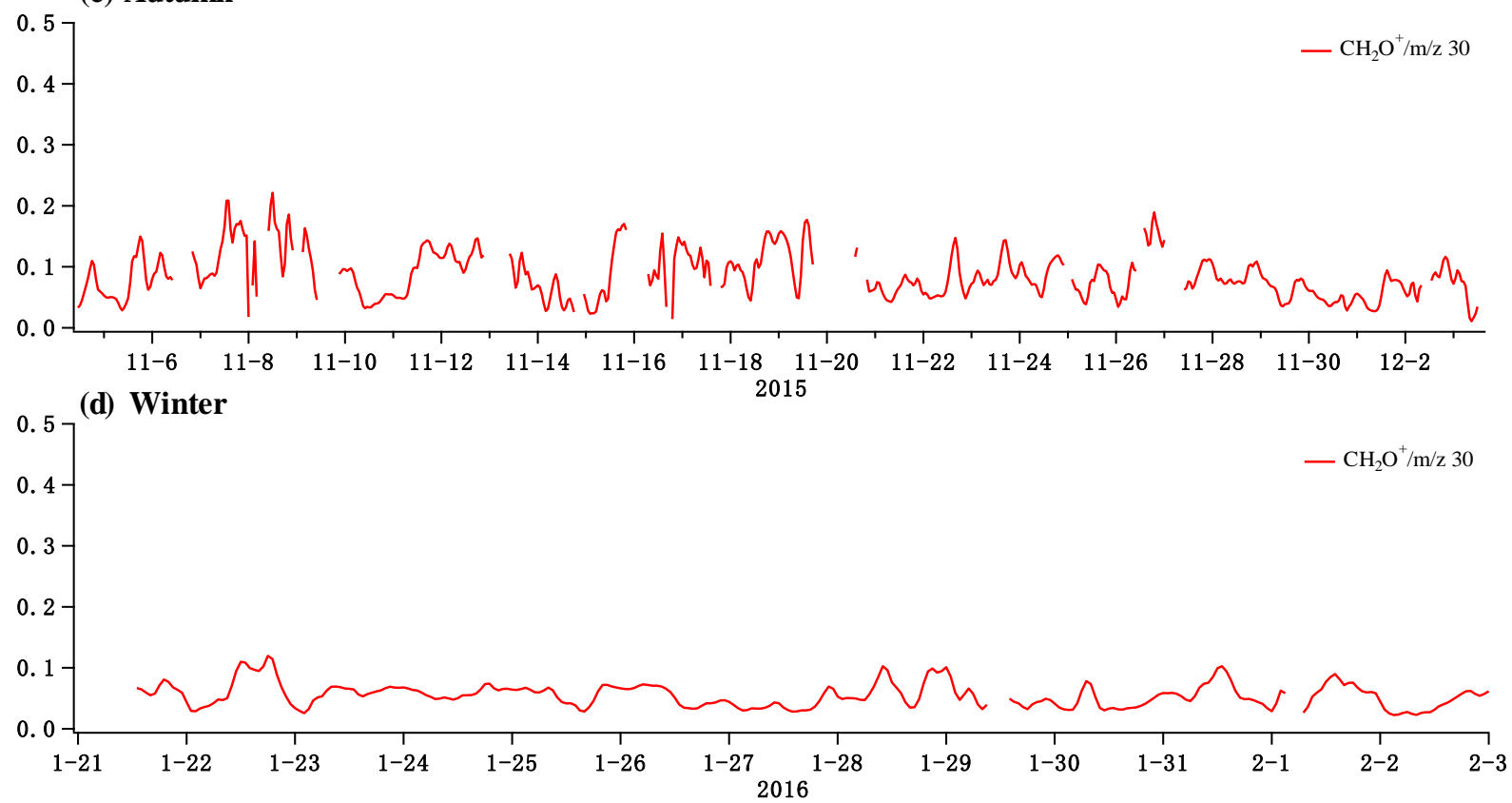

Figure S10. Time series of the contributions of $\mathrm{CH}_{2} \mathrm{O}^{+}$in $\mathrm{m} / \mathrm{z} 30$ and $\mathrm{CH}_{2} \mathrm{O}_{2}{ }^{+}$in $\mathrm{m} / \mathrm{z} 46$ in the HR data of $\mathrm{PM}_{1}$ for spring (a), summer (b), autumn (c) and winter (d). (High-resolution mass spectra at $\mathrm{m} / \mathrm{z} 46$ only contains $\mathrm{NO}_{2}{ }^{+}$in spring, autumn and winter). 
(a)

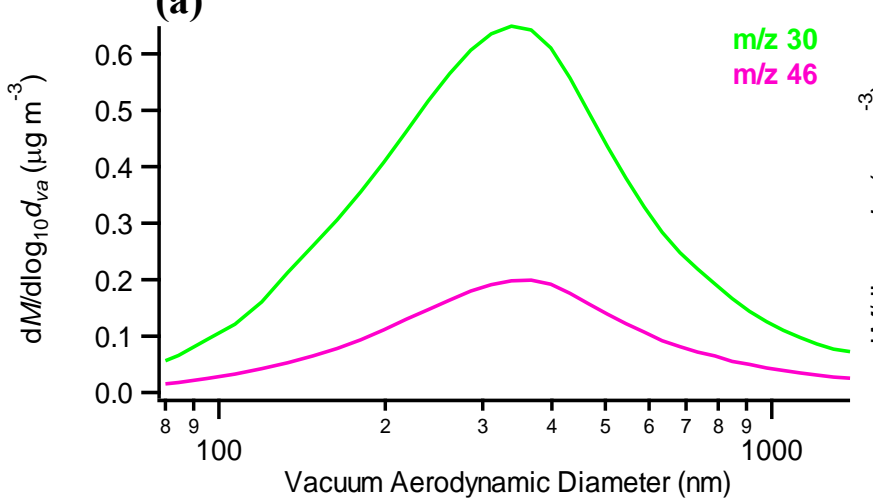

(c)
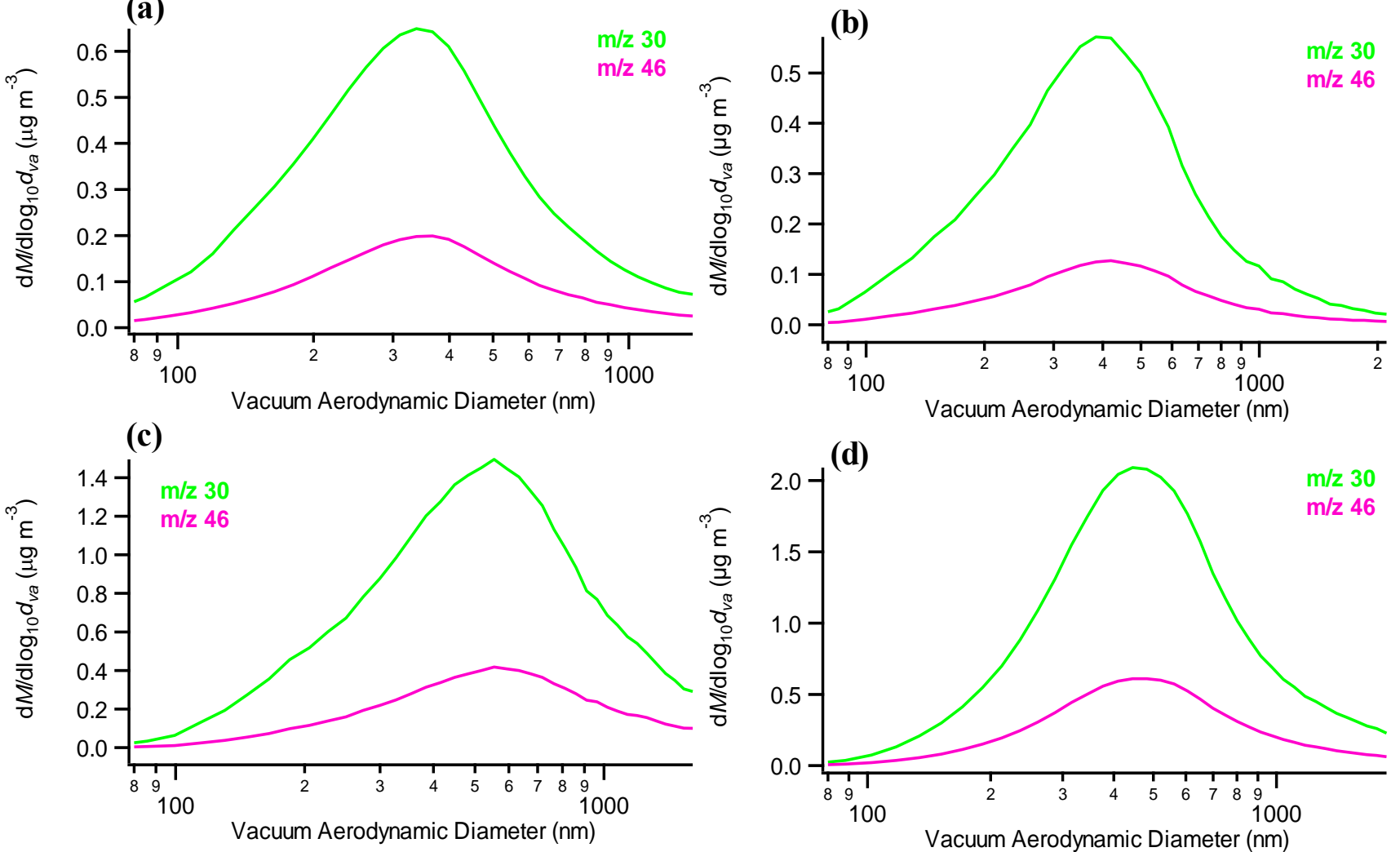

Figure S11. Average size distributions of m/z 30 and m/z 46 in spring (a), summer (b), autumn (c) and winter (d). 

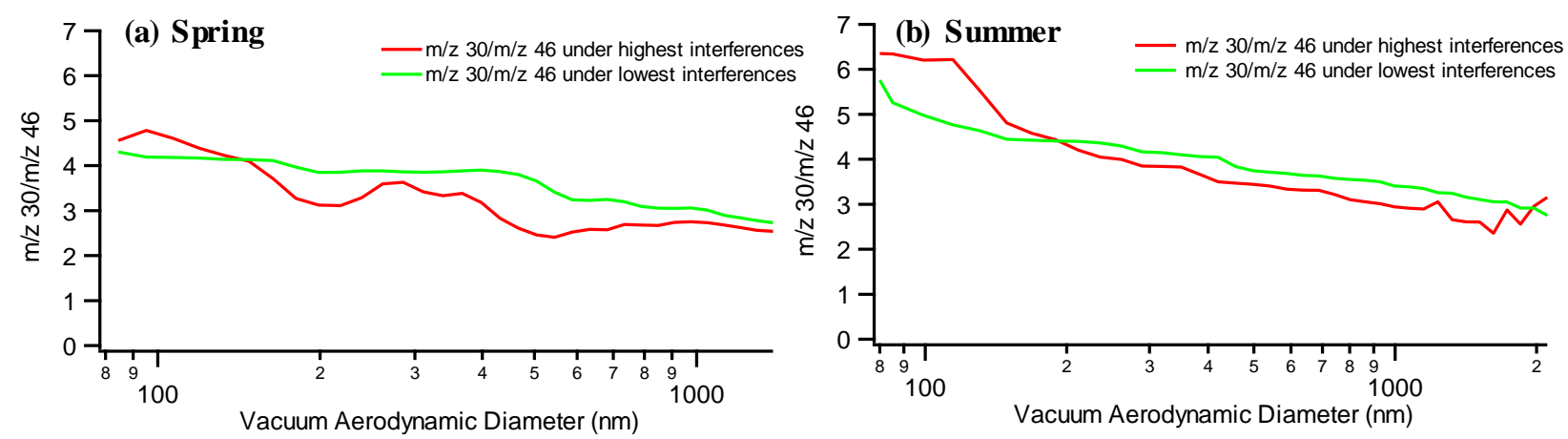

(c) Autumn

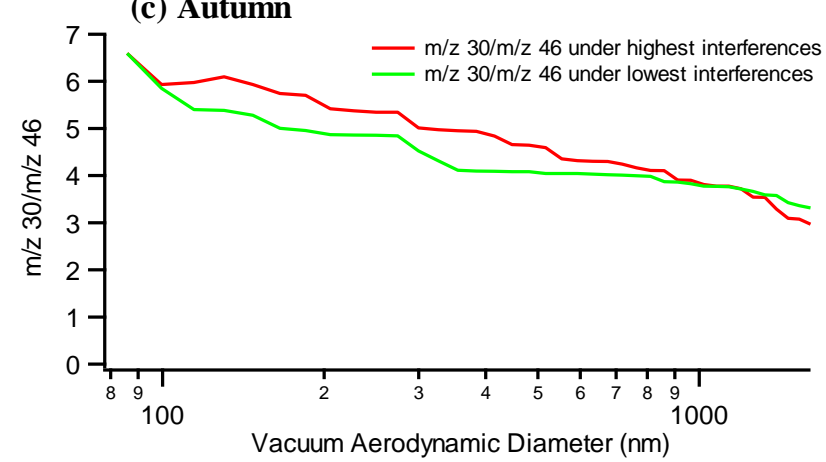

128 Figure S12. Average size distributions of $\mathrm{m} / \mathrm{z} 30 / \mathrm{m} / \mathrm{z} 46$ ratio under under highest $(>15 \%)$ and lowest interferences $(<5 \%)$ $\mathrm{CH}_{2} \mathrm{O}_{\mathrm{X}}{ }^{+}$interferences in spring (a), summer (b), autumn (c). 

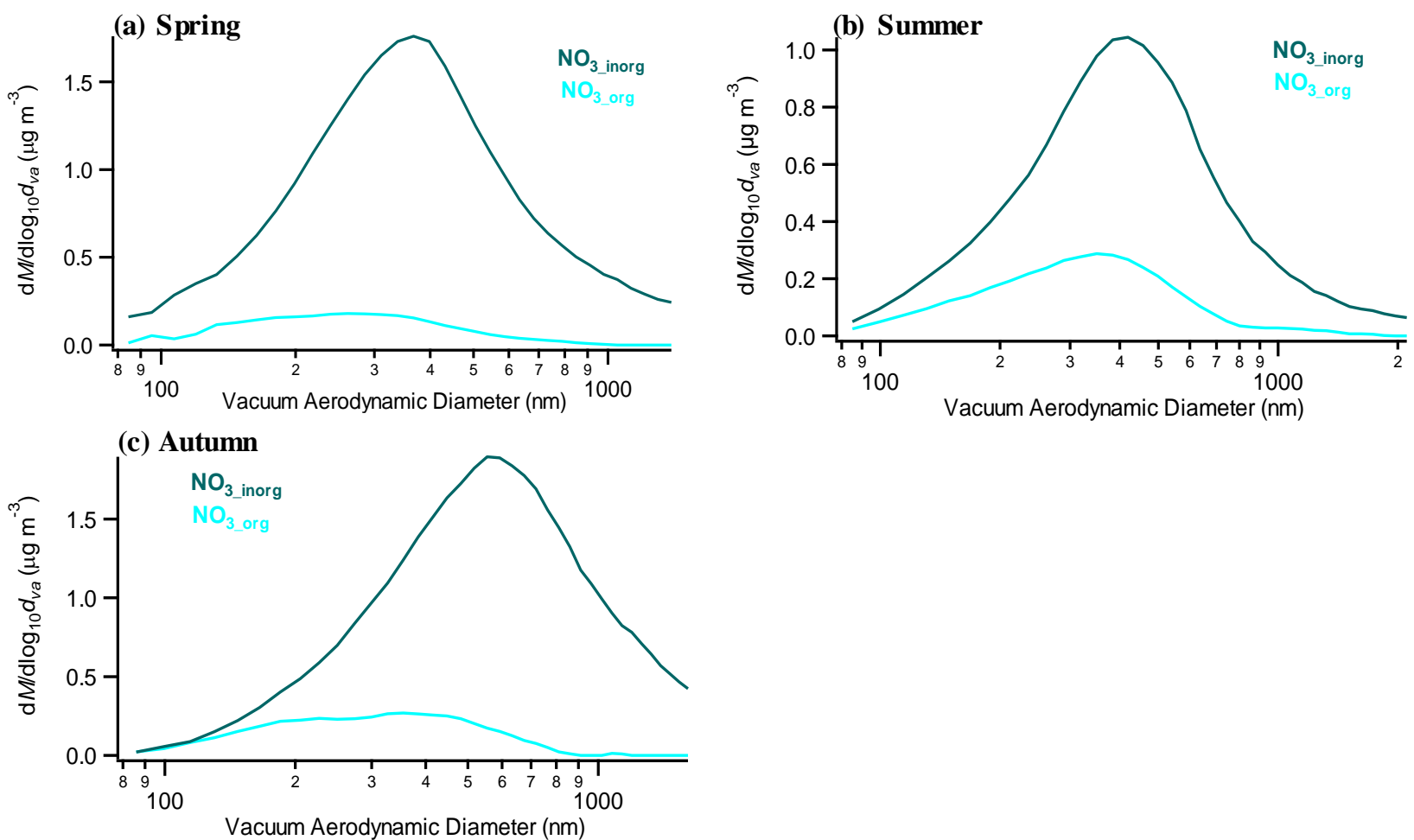

131 Figure S13. Average size distributions of organic and inorganic nitrates calculated using the size distributions of $\mathrm{m} / \mathrm{z} 30 / \mathrm{m} / \mathrm{z}$ 13246 ratio and $\mathrm{NO}^{+} / \mathrm{NO}_{2}{ }^{+}$ratio method in spring (a), summer (b), autumn (c). 


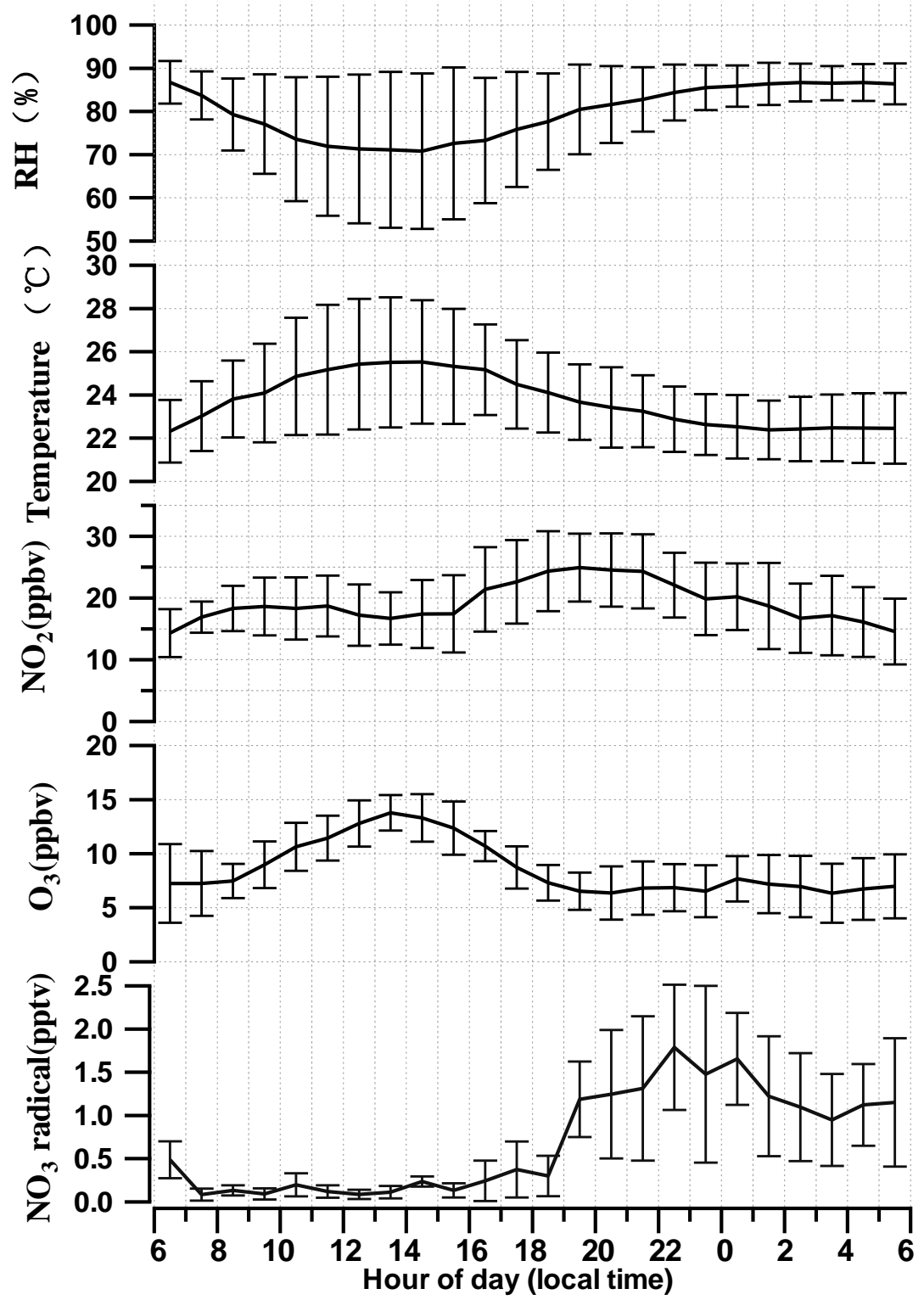

Figure S14.Diurnal trends of relative hu mid ity $(\mathrm{RH})$, temperature, $\mathrm{NO}_{2}, \mathrm{O}_{3}$ and calculated $\mathrm{NO}_{3}$ radicals in spring (The solid lines indicate the mean concentration and the error bars indicate the standard error). 
(a)
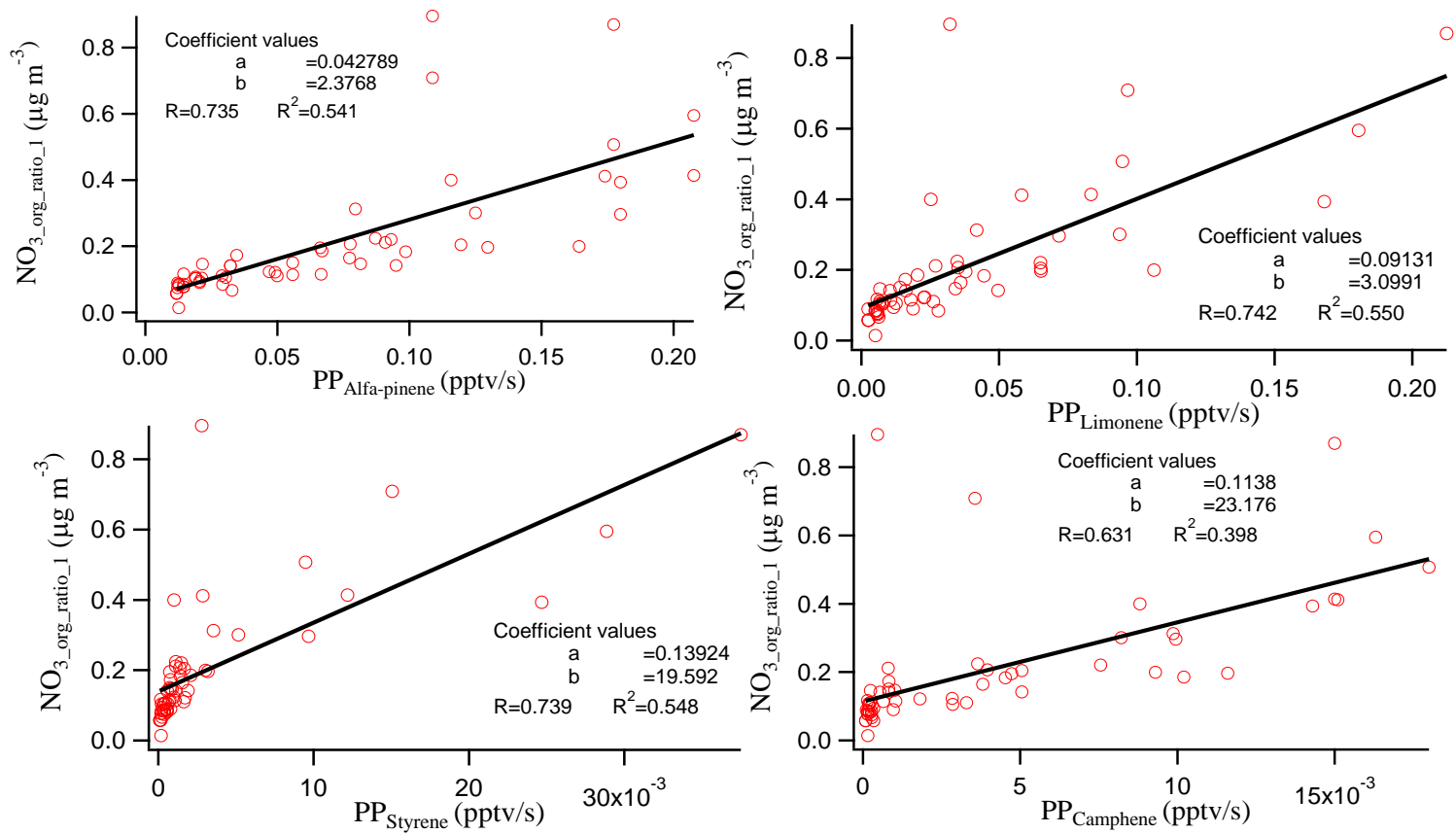

(b)
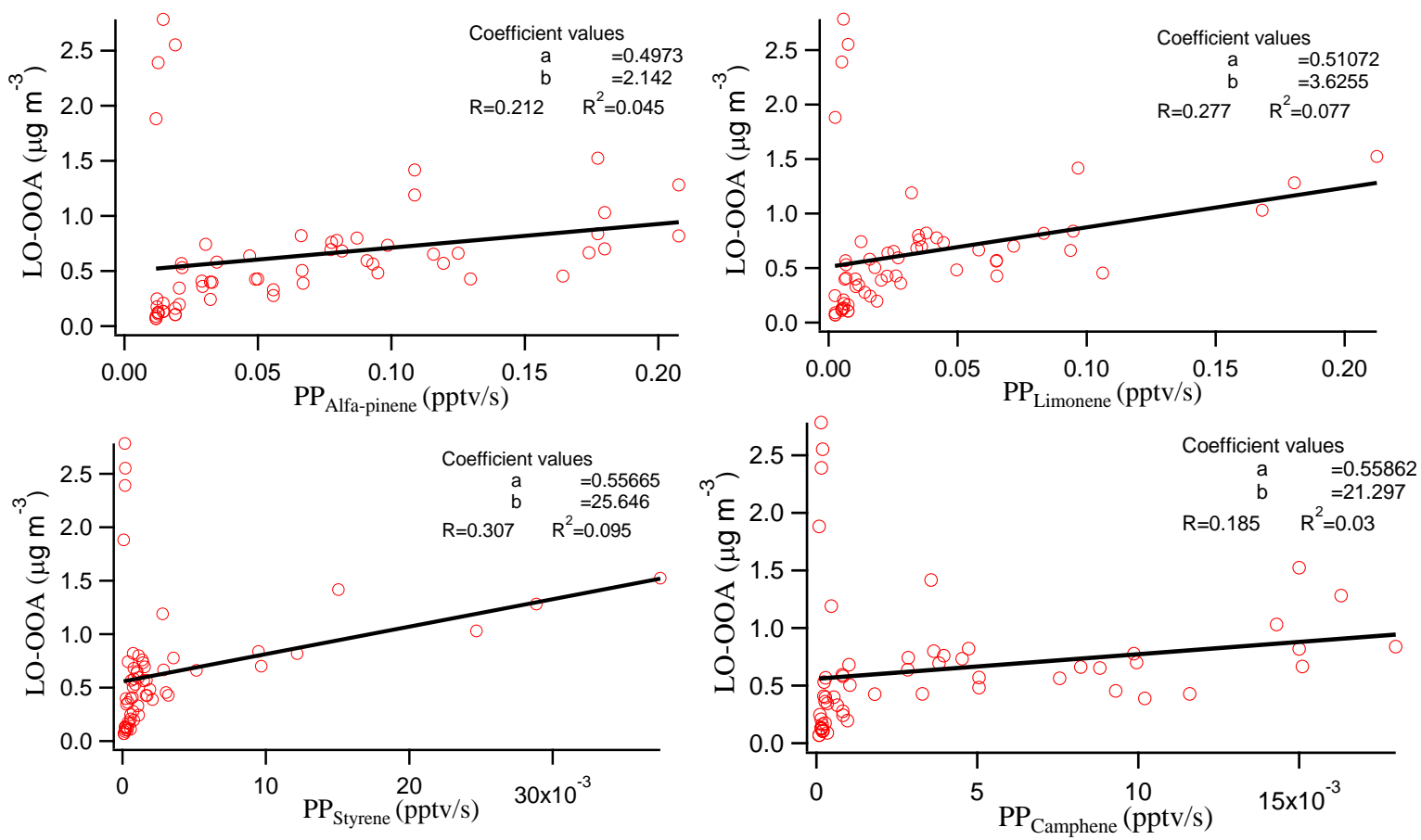
(c)
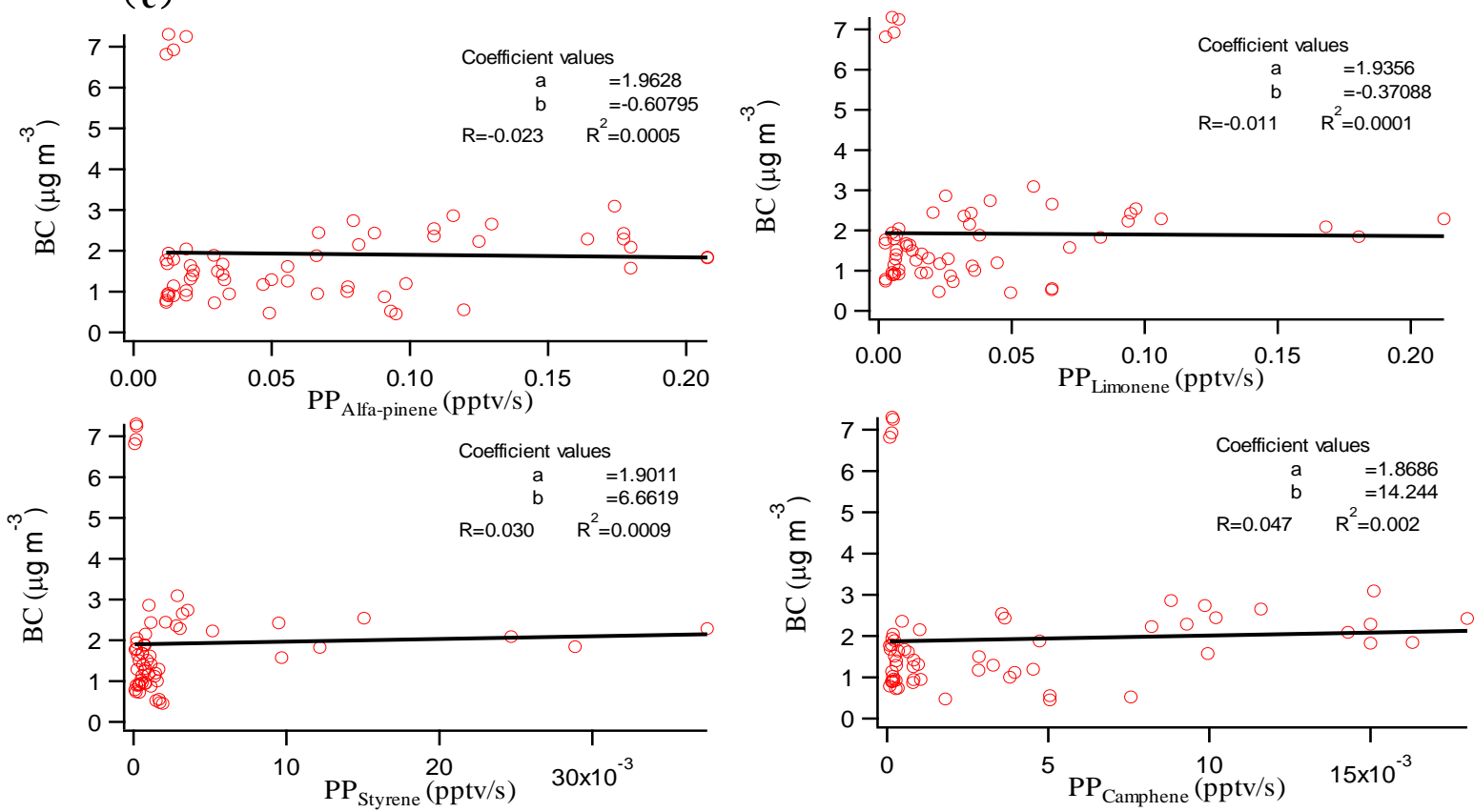

Figure S15. (a) Correlations between $\mathrm{NO}_{3 \_ \text {on__atio_1 }}$ with PP of $\alpha$-pinene, limonene, styrene and camphene during 2:00-6:00

140 for the spring campaign; (b) Correlation between LO-OOA with PP of $\alpha$-pinene, limonene, styrene and camphene during 141 2:00-6:00 for the spring campaign; (c) Corre lation between BC with PP of $\alpha$-pinene, limonene, styrene and camphene during 142 2:00-6:00 for the spring campaign 
(a)

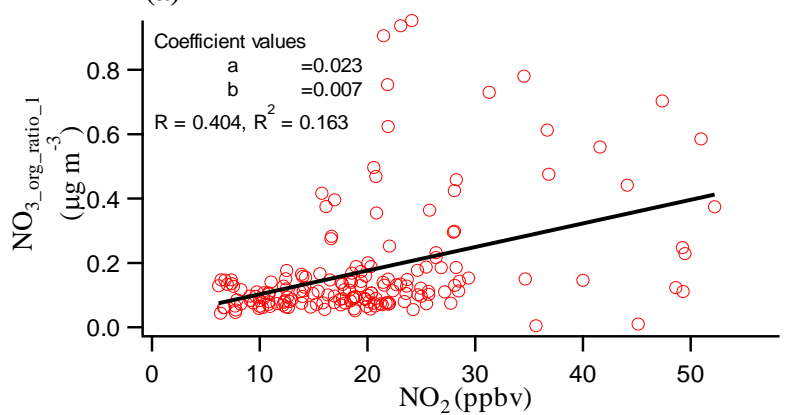

(c)

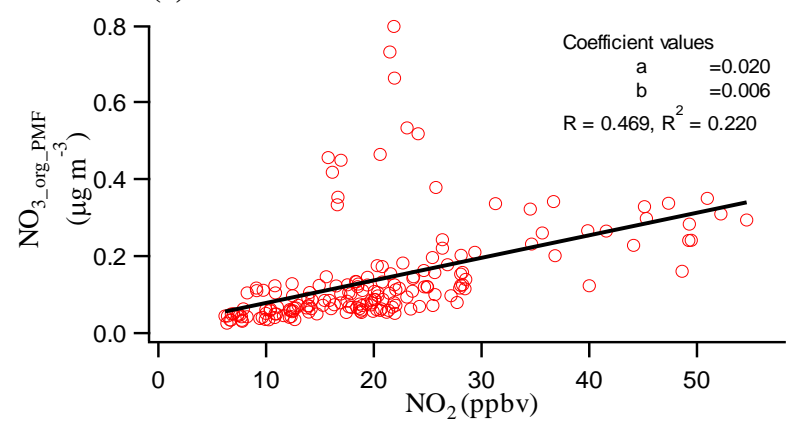

(b)

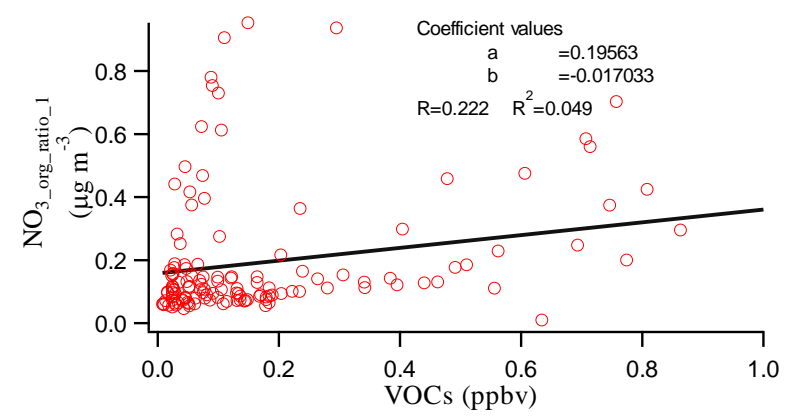

(d)

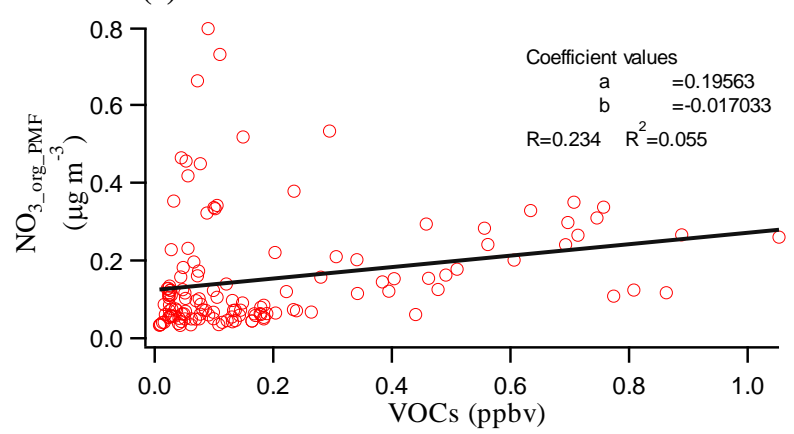

Figure S16.Corre lation of $\mathrm{NO}_{3}$ _org_ratio_1 and $\mathrm{NO}_{2}(\mathrm{a})$; $\mathrm{NO}_{3}$ _org_ratio_1 and VOCs (the sum of $\alpha$-pinene, limonene, styrene and camphene) (b); $\mathrm{NO}_{3 \_ \text {org_PMF }}$ and $\mathrm{NO}_{2}$ (c) and $\mathrm{NO}_{3 \_ \text {org_PMF }}$ and VOCs (the sum of $\alpha$-pinene, limonene, styrene and camphene) (d) during the springtime.

Table S1.The correlation coefficients $(\mathrm{R})$ of $\mathrm{NO}_{3}$, org and $\mathrm{NO}_{3}$, inorg in 3- to 5-factors solutions estimated by PMF method with these estimated by NOx method, respectively.

\begin{tabular}{|c|c|c|c|c|c|}
\hline \multicolumn{2}{|c|}{ 3-factor solution } & \multicolumn{2}{|c|}{ 4-factor solution } & \multicolumn{2}{|l|}{ 5-factor solution } \\
\hline $\begin{array}{l}N O_{3, \text { org }} \\
(\mathrm{NOx} \text { vs. PMF) }\end{array}$ & $\begin{array}{l}N O_{3, \text { inorg }} \\
\text { (NOx vs. PMF) }\end{array}$ & $\begin{array}{l}N O_{3, \text { org }} \\
(\mathrm{NOx} \text { vs. PMF) }\end{array}$ & $\begin{array}{l}N O_{3, \text { inorg }} \\
\text { (NOx vs. PMF) }\end{array}$ & $\begin{array}{l}N O_{3, \text { org }} \\
(\mathrm{NOx} \text { vs. PMF) }\end{array}$ & $\begin{array}{l}N O_{3, \text { inorg }} \\
\text { (NOx vs. PMF) }\end{array}$ \\
\hline 0.82 & 0.92 & 0.81 & 0.90 & 0.80 & 0.91 \\
\hline 1.21 & 0.76 & 1.15 & 0.78 & 1.20 & 0.82 \\
\hline 0.82 & 0.87 & 0.82 & 0.88 & 0.81 & 0.90 \\
\hline 1.53 & 0.70 & 1.50 & 0.65 & 1.45 & 0.64 \\
\hline 0.77 & 0.86 & 0.75 & 0.85 & 0.76 & 0.83 \\
\hline 0.81 & 0.85 & 0.76 & 0.82 & 0.75 & 0.78 \\
\hline
\end{tabular}

150 
Table S2.The mass fraction of $\mathrm{NO}^{+}$and $\mathrm{NO}_{2}{ }^{+}$in OA factors when FPEAK is 0 and the standard deviations (SD) of $\mathrm{NO}^{+}$and $\mathrm{NO}_{2}{ }^{+}$in OA factors across different FPEAK values (from -1.0 to 1.0 )

\begin{tabular}{|c|c|c|c|c|c|}
\hline & & & HOA & LO-OOA & MO-OOA \\
\hline \multirow[t]{4}{*}{ Spring } & \multirow[t]{2}{*}{$\mathrm{NO}^{+}$} & FPEAK $=0$ & $1.3^{*} 10^{-2}$ & $1.4^{*} * 10^{-2}$ & $9.8^{*} * 10^{-5}$ \\
\hline & & SD & $1.2^{*} 10^{-5}$ & $6.9 * 10^{-4}$ & $2.4 * 10^{-5}$ \\
\hline & \multirow[t]{2}{*}{$\mathrm{NO}_{2}{ }^{+}$} & FPEAK $=0$ & $1.2^{*} 10^{-2}$ & $1.5^{*} 10^{-4}$ & $3.0^{*} 10^{-8}$ \\
\hline & & SD & $4.6 * 10^{-4}$ & $2.0^{*} 10^{-5}$ & $8.6^{*} 10^{-8}$ \\
\hline \multirow[t]{4}{*}{ Summer } & \multirow[t]{2}{*}{$\mathrm{NO}^{+}$} & FPEAK $=0$ & $1.5^{*} 10^{-2}$ & $1.0^{*} 10^{-2}$ & $1.2^{*} 10^{-2}$ \\
\hline & & SD & $6.8 * 10^{-4}$ & $1.1 * 10^{-3}$ & $2.0^{*} 10^{-3}$ \\
\hline & \multirow[t]{2}{*}{$\mathrm{NO}_{2}{ }^{+}$} & FPEAK $=0$ & $1.5^{*} 10^{-6}$ & $6.7 * 10^{-4}$ & $1.8^{*} 10^{-3}$ \\
\hline & & SD & $2.4 * 10^{-1}$ & $9.3 * 10^{-5}$ & $3.5^{*} 10^{-4}$ \\
\hline \multirow[t]{4}{*}{ Autumn } & \multirow[t]{2}{*}{$\mathrm{NO}^{+}$} & FPEAK $=0$ & $1.1 * 10^{-2}$ & $3.1 * 10^{-2}$ & $1.0^{*} 10^{-2}$ \\
\hline & & SD & $2.2^{*} 10^{-5}$ & $2.5^{*} 10^{-5}$ & $2.7 * 10^{-5}$ \\
\hline & \multirow[t]{2}{*}{$\mathrm{NO}_{2}{ }^{+}$} & FPEAK $=0$ & $7.0^{*} 10^{-8}$ & $9.8^{*} 10^{-8}$ & $2.8^{*} 10^{-1}$ \\
\hline & & SD & $2.5^{*} 10^{-9}$ & $2.7 * 10^{-8}$ & $3.0^{*} 10^{-8}$ \\
\hline
\end{tabular}

Table S3.The average campaign concentrations of VOCs measured with an automated in situ gas -chromatography mass spectrometer (GC-MS), their reaction rate coefficients for reacting with $\mathrm{NO}_{3}$ radical and the production potential from $\mathrm{NO} 3+\mathrm{VOC}$ in spring.

\begin{tabular}{lccc}
\hline VOC species & Mean concentration (ppbv) & Rate Coefficient & $\begin{array}{c}\text { Production potential } \\
\text { (pptv/s) }\end{array}$ \\
\hline $\mathbf{1 , 2 , 3}$-Trimethylbenzene & 0.057 & $1.90 \mathrm{E}-15$ & $3.72 \mathrm{E}-06$ \\
\hline $\mathbf{1 , 2 , 4 - T r i m e t h y l b e n z e n e ~}$ & 0.177 & $1.80 \mathrm{E}-15$ & $1.10 \mathrm{E}-05$ \\
\hline $\mathbf{1 , 3 , 5}$-Trimethylbenzene & 0.051 & $8.80 \mathrm{E}-16$ & $1.54 \mathrm{E}-06$ \\
\hline $\mathbf{1 , 3 - B u t a d i e n e}$ & 0.052 & $1.00 \mathrm{E}-13$ & $1.79 \mathrm{E}-04$ \\
\hline 1-Butene & 0.415 & $1.32 \mathrm{E}-14$ & $1.89 \mathrm{E}-04$ \\
\hline $\mathbf{1 - H e x e n e}$ & 0.022 & $1.20 \mathrm{E}-14$ & $9.06 \mathrm{E}-06$ \\
\hline $\mathbf{1 - P e n t e n e}$ & 0.022 & $1.20 \mathrm{E}-14$ & $9.27 \mathrm{E}-06$ \\
\hline $\mathbf{2 , 2 , 4 - T r i m e t h y l p e n t a n e}$ & 0.068 & $9.00 \mathrm{E}-17$ & $2.10 \mathrm{E}-07$ \\
\hline $\mathbf{2 , 2}$-Dimethylbutane & 0.199 & $4.40 \mathrm{E}-16$ & $3.01 \mathrm{E}-06$ \\
\hline $\mathbf{2 , 3 , 4 - T r i m e t h y l p e n t a n e}$ & 0.022 & $1.90 \mathrm{E}-16$ & $1.44 \mathrm{E}-07$ \\
\hline $\mathbf{2 , 3 - D i m e t h y l b u t a n e}$ & 0.299 & $4.40 \mathrm{E}-16$ & $4.54 \mathrm{E}-06$ \\
\hline
\end{tabular}




\begin{tabular}{|c|c|c|c|}
\hline 2,3-Dimethylpentane & 0.293 & $1.50 \mathrm{E}-16$ & $1.51 \mathrm{E}-06$ \\
\hline 2-Methylheptane & 0.034 & $1.90 \mathrm{E}-16$ & $2.20 \mathrm{E}-07$ \\
\hline 2-Methylhexane & 0.514 & $1.50 \mathrm{E}-16$ & $2.66 \mathrm{E}-06$ \\
\hline 2-Methylpentane & 1.582 & $1.80 \mathrm{E}-16$ & $9.81 \mathrm{E}-06$ \\
\hline 3-Methylheptane & 0.027 & $1.90 \mathrm{E}-16$ & $1.74 \mathrm{E}-07$ \\
\hline 3-Methylhexane & 0.534 & $1.50 \mathrm{E}-16$ & $2.76 \mathrm{E}-06$ \\
\hline 3-Methylpentane & 1.411 & $2.20 \mathrm{E}-16$ & $1.07 \mathrm{E}-05$ \\
\hline Acetaldehyde & 1.249 & $2.70 \mathrm{E}-15$ & $1.16 \mathrm{E}-04$ \\
\hline Acetylene & 0.941 & $5.10 \mathrm{E}-17$ & $1.65 \mathrm{E}-06$ \\
\hline Acrolein & 0.042 & $3.30 \mathrm{E}-15$ & $4.73 \mathrm{E}-06$ \\
\hline Benzene & 0.599 & $3.00 \mathrm{E}-17$ & $6.19 \mathrm{E}-07$ \\
\hline cis-2-Pentene & 0.005 & $3.70 \mathrm{E}-13$ & $6.57 \mathrm{E}-05$ \\
\hline Cyclohexane & 1.164 & $1.40 \mathrm{E}-16$ & $5.61 \mathrm{E}-06$ \\
\hline Cyclopentane & 0.416 & $1.40 \mathrm{E}-16$ & $2.00 \mathrm{E}-06$ \\
\hline Ethane & 1.567 & $1.00 \mathrm{E}-17$ & $5.40 \mathrm{E}-07$ \\
\hline Ethylbenzene & 0.563 & $1.20 \mathrm{E}-16$ & $2.34 \mathrm{E}-06$ \\
\hline Isoprene & 0.032 & $6.96 \mathrm{E}-13$ & $7.76 \mathrm{E}-04$ \\
\hline m/p-Xylene & 0.602 & $3.80 \mathrm{E}-16$ & $7.88 \mathrm{E}-06$ \\
\hline Methacrolein & 0.012 & $3.40 \mathrm{E}-15$ & $1.44 \mathrm{E}-06$ \\
\hline Methylcyclohexane & 0.172 & $1.40 \mathrm{E}-16$ & $8.29 \mathrm{E}-07$ \\
\hline Methylcyclopentane & 0.673 & $1.40 \mathrm{E}-16$ & $3.25 \mathrm{E}-06$ \\
\hline n-Butanal & 0.044 & $1.10 \mathrm{E}-14$ & $1.68 \mathrm{E}-05$ \\
\hline n-Butane & 1.848 & $4.60 \mathrm{E}-17$ & $2.93 \mathrm{E}-06$ \\
\hline n-Decane & 0.060 & $2.80 \mathrm{E}-16$ & 5.74E-07 \\
\hline n-Heptane & 0.351 & $1.50 \mathrm{E}-16$ & $1.81 \mathrm{E}-06$ \\
\hline n-Hexane & 1.916 & $1.10 \mathrm{E}-16$ & $7.25 \mathrm{E}-06$ \\
\hline n-Nonane & 0.033 & $2.30 \mathrm{E}-16$ & $2.59 \mathrm{E}-07$ \\
\hline n-Pentanal & 0.128 & $1.50 \mathrm{E}-14$ & $6.61 \mathrm{E}-05$ \\
\hline n-Pentane & 0.593 & $8.70 \mathrm{E}-17$ & $1.78 \mathrm{E}-06$ \\
\hline n-Propylbenzene & 0.029 & $6.00 \mathrm{E}-16$ & $6.01 \mathrm{E}-07$ \\
\hline Octane & 0.064 & $1.90 \mathrm{E}-16$ & $4.17 \mathrm{E}-07$ \\
\hline o-Xylene & 0.464 & $3.80 \mathrm{E}-16$ & $6.06 \mathrm{E}-06$ \\
\hline
\end{tabular}




\begin{tabular}{llll}
\hline Propanal & 0.144 & $6.31 \mathrm{E}-15$ & $3.12 \mathrm{E}-05$ \\
\hline Propane & 3.678 & $7.00 \mathrm{E}-17$ & $8.86 \mathrm{E}-06$ \\
\hline Propene & 0.477 & $9.54 \mathrm{E}-15$ & $1.57 \mathrm{E}-04$ \\
\hline Styrene & 0.194 & $1.50 \mathrm{E}-12$ & $1.00 \mathrm{E}-02$ \\
\hline Toluene & 3.120 & $7.00 \mathrm{E}-17$ & $7.52 \mathrm{E}-06$ \\
\hline Alpha-Pinene & 0.391 & $6.21 \mathrm{E}-12$ & $8.36 \mathrm{E}-02$ \\
\hline Beta-Pinene & 0.013 & $2.51 \mathrm{E}-12$ & $1.10 \mathrm{E}-03$ \\
\hline Camphene & 0.276 & $6.20 \mathrm{E}-13$ & $5.91 \mathrm{E}-03$ \\
\hline Limonene & 0.137 & $1.22 \mathrm{E}-11$ & $5.77 \mathrm{E}-02$ \\
\hline
\end{tabular}




\section{References}

Crowley, J.N., Thieser, J., Tang, M.J., Schuster, G., Bozem, H., Beygi, Z.H., Fischer, H., Diesch, J.M., Drewnick, F., Borrmann, S., Song, W., Yassaa, N., Williams, J., Pöhler, D., Platt, U., Lelieveld, J.: Variable lifetimes and loss mechanis ms for NO3and N2O5during the DOMINO campaign: Contrasts between marine, urban and continental air. Atmos. Chem. Phys. 11, 10853-10870, https://doi.org/10.5194/acp-11-10853-2011, 2011.

Dentener, F. J. and Crutzen, P. J.: Reaction of N2O5 on tropospheric aerosols: Impact on the global distributions of NOx , O3, and OH, J. Geophys. Res., 98, 7149-7163, https://doi.org/10.1029/92JD02979, 1993.

Liu, X.G., Zhang, Y.H., Wen, M.T., Wang, J.L., Jung, J.S., Chang, S.-Y., Hu, M., Zeng, L.M. and Kim, Y.J.: A closure study of aerosol hygroscopic growth factor during the 2006 Pearl River Delta Campaign. Adv. Atmos. Sci, 27, 947-956, https://doi.10.1007/s00376-009-9150-z, 2010.

Saunders, S.M., Jenkin, M.E., Derwent, R.G., Pilling, M.J.: Protocol for the development of the Master Chemical Mechanism, MCM v3 (Part A): tropospheric degradation of non-aromatic volatile organic compounds. Atmos. Chem. Phys. 3, 161-180, https://doi.org/10.5194/acp-3-161-2003, 2003.

Xu, L., Guo, H., Boyd, C.M., Kle in, M., Bougiatioti, A., Cerully, K.M., Hite, J.R., Isaacman-VanWertz, G., Kreisberg, N.M., Knote, C., Olson, K., Koss, A., Goldstein, A.H., Hering, S. V., de Gou w, J., Bau mann, K., Lee, S. -H., Nenes, A., Weber, R.J., Ng, N.L.: Effects of anthropogenic emissions on aerosol formation from isoprene and monoterpenes in the southeastern United States.Proc. Natl. Acad. Sci. 112, 37-42, https://doi.org/10.1073/pnas.1417609112, 2015. 